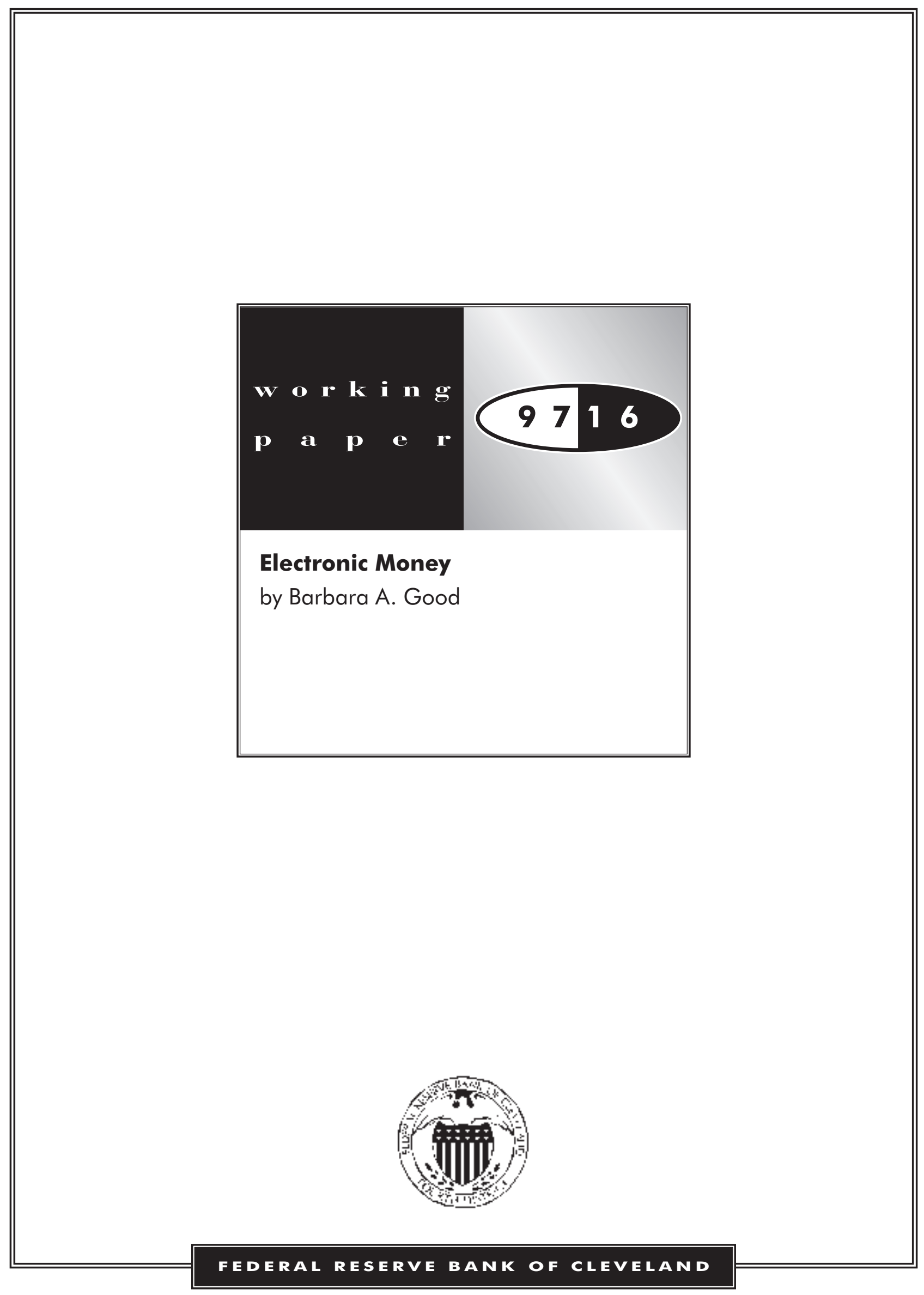


A new technology brings with it not only the potential for success, but also a never-ending series of questions regarding its design, its value to the user, its ultimate use and acceptability. Electronic money in its various forms, has the potential of changing the retail payments arena in a way that has not happened since the advent of the credit card. But, at this time it is only potential.

Stored-value cards may help to make the transition from paper-based payments to electronically-based payments more likely as these systems, especially stored value cards, incorporate familiar aspects of using money in a way that could prove to be both convenient and acceptable to the public.

This paper will attempt to identify the issues that need to be addressed in order for stored-value cards and other electronic money systems to become a major payment mechanism in the global financial market. These new payments devices require a thorough evaluation of the appropriate regulatory, legal, and policy responses, as well as an estimate of the market acceptance (diffusion of this technology) throughout the financial and social system. These types of cards have the potential to have far reaching effects, if they are accepted by both consumers and merchants. 


\title{
"ELECTRONIC MONEY"
}

\author{
by \\ Barbara A. Good \\ Federal Reserve Bank of Cleveland \\ Economic Research Department \\ August 1997
}




\section{Introduction}

A new technology brings with it not only the potential for success, but also a never-ending series of questions regarding its design, its value to the user, its ultimate use and acceptability. In this paper the term smart cards, stored-value cards and electronic money will be used to denote money in the form of "value", whether it is issued in card-based or network-based form. ${ }^{1}$ Although there are technical differences, the term "smart card" is generally used interchangeably with stored-value card. There are many questions regarding these new payments devices that need to be answered by the designers, issuers, and regulators of these devices. This innovation has the potential of changing the retail payments arena in a way that has not happened since the advent of the credit card. But, at this time it is only potential.

Although there has been significant effort made to eliminate paper-based payment transactions, the basic way of handling payments by consumers has not changed. Stored-value cards may help to make the transition from paper-based payments to electronically-based payments more likely as these cards incorporate familiar aspects of using money in a way that could prove to be both convenient and acceptable to the public.

As money technology has evolved, methods of payment have also changed, but cash still often remains a preferred method of payment by many people. Over the past few decades various media and industry experts have predicted the demise of cash and the advent of the "cashless" society. However, recent survey results showed that the preferred form of payments by consumers and merchants was still cash. Table 1 presents the results of that survey. 


\section{TABLE 1}

\begin{tabular}{|c|c|}
\hline \multicolumn{2}{||c||}{$\begin{array}{c}\text { Preferred Forms of Payments } \\
\text { by Consumers }\end{array}$} \\
\hline \hline Cash & $54.2 \%{ }^{*}$ \\
\hline 3rd Party Credit Cards (i.e., Visa) & $38.5 \%$ \\
\hline Check & $23.4 \%$ \\
\hline Store Credit Cards & $6.5 \%$ \\
\hline Debit Cards & $1.0 \%$ \\
\hline Other & $1.1 \%$ \\
\hline
\end{tabular}

*Percentages will not add to $100 \%$, due to format of questions asked.

The survey, conducted by Ernst \& Young, showed also that $58 \%$ of retailers had a preference for cash transactions. ${ }^{2}$ The evidence from this survey is noteworthy, as it is easy to see the vast market potential for a product such as the smart card that is designed to be a replacement primarily for cash transactions.

The number of cash purchases far exceeded any other payment method, although their value accounts for less than 20 percent of the value of total consumer transactions on a monthly basis. Cash is used most often at food stores, for purchases at gasoline filling stations, and for dining out. The reasons given for using cash were that 1) it is convenient for small, inexpensive purchases, 2) force of habit, and 3) the recipient preferred or only accepted cash. ${ }^{3}$

Even assuming that stored-value cards capture only a small fraction of their targeted markets, the potential of the market for stored-value cards has been estimated to be roughly the size of the market for traveler's checks $-\$ 20$ billion transacted annually. ${ }^{4}$ Although most consumer transactions are made with cash, these transactions represent only a small share of the total expenditures. (Low income 
families are an exception to this statement.) The Congressional Budget Office has estimated that cash payments account for approximately $\$ 1$ trillion of consumer expenditures, roughly 20 per cent of net consumer expenditures of about $\$ 5$ trillion. For every 1 percent of cash transactions that were replaced with stored-value cards, issuers would sell $\$ 10$ billion worth of cash balances on cards. ${ }^{5}$ It is no wonder that the major players in this new payment form wax so enthusiastic about the prospects of their devices.

This paper will identify the major issues that need to be addressed in order for stored-value cards to become a major payment mechanism in the global financial market. These cards could replace a portion of the cash transactions, the checks written, and possibly the credit card purchases if they are accepted by the consumers and merchants, and if they are designed in a way that replicates what people like most about cash in a more secure and convenient form.

Section II presents the history and development of stored-value or "smart" cards and an evaluation of their potential as a replacement and/or enhancement to the current payments system. Stored-value cards are predicted to become a kind of electronic purse which could substitute for coins and currency, and even paper checks. Network based systems of electronic money will be discussed due to their impact on the development of electronic commerce on the Internet.

These new payments devices require a thorough evaluation of the appropriate regulatory, legal, and policy responses, as well as an estimate of the market acceptance throughout the financial and social system. These types of cards have the potential to have far reaching effects, if they are accepted by both consumers and merchants.

Section III looks at the regulatory environment and the problems that the 
competing regulatory agencies and systems are likely to have in relation to the adoption and diffusion of these new payments systems.

At this time several competing, and conflicting designs, have been developed, with no consensus on the dominant design. With the recent announcements of several organizations' acceptance of Java as a standard development software ${ }^{6}$, the standards for the protocol of cybermoney for Internet commerce are progressing more rapidly than the standards and design of stored-value cards. Lack of a dominant design coupled with the lack of interoperability has the potential to fragment the market in such a way that none of the current electronic money schemes will prosperd. Other issues such as privacy and security of information also are important in the design of these technologies. Section IV will address the different designs that are being considered and identify issues related to multiple designs.

Finally, Section $\mathrm{V}$ will discuss the integration issues of multi-national electronic money and the design issues that need to be addressed and make recommendations regarding a potential international policy response, forum and format for addressing these issues. Without worldwide financial institution and governmental support for standards and regulations these instruments may be only an adjunct payment method, and may never reach their forecasted potential. 


\section{SECTION II. The Current Technology}

\section{Overview}

\section{History of Smart Cards}

The smart card has been defined many ways, but is generally defined as a "portable data storage device with intelligence (chip memory) and provisions for identity and security." $\quad$ In their simplest forms, these cards are small microcomputers -lacking only external power supply, displays, and keyboards. With some of the newly designed peripherals, they can even have keyboards and a display. One of the most widely tested stored-value cards offered by Mondex, has an electronic wallet, available as an optional accessory, with both of these peripheral devices.

The microprocessor chip in a stored-value card is specialized and customdesigned, generally with specific patented control and production circuits. Certain data, primarily related to the security of the card, can be entered only at the time of manufacture. ${ }^{8}$ In addition to a microprocessor each card generally has several kilobytes of permanent memory, both rewriteable and nonrewriteable.

The first implementation of microelectronic devices in plastic substrate is attributed to a Japanese inventor, Kunitaka Arimura, in $1970 .^{9}$ His patent focused primarily on the embedding of the chip rather than on the functional features. ${ }^{10}$

In 1974, a French journalist, Roland Moreno, filed his first patent on "an independent electronic object with memory." Moreno focused on the functional aspects of the card, including the use of secret keywords (PINs) for access to the card's stored data. ${ }^{11}$ At the same time, Moreno founded Societe' Internationale pour l'Innovation (Innovatron) from which most current chip card manufacturers license the smart card technology. 
Honeywell Bull licensed this technology and produced and shipped the first smart card with an embedded microprocessor in 1979 to Innovatron. The card proved unreliable, however, due to the design. Bull then developed another type of single chip card and filed a patent for it. By the beginning of the 1980s, several field tests were planned. ${ }^{12}$

The most important trial was conducted by the French Bank Card Association between 1982 and 1984. This was a joint venture between the Blue Card (related to Visa), the Green Card (related to MasterCard), and the Telecommunications Administration (the French phone company administrator). One goal of the venture was to establish the best technology for smart cards, so each manufacturer contributed a different technical approach. The result was a hybrid card employing both a chip and a magnetic stripe, ensuring compatibility with the existing magnetic-stripe technology already deployed for credit cards. ${ }^{13}$

Another trial involved the use of university cards in France and elsewhere beginning in 1983. The results of these experiments seemed promising enough to form the basis for the current U.S. trials.

The turning point between the early and current experiences in the world of smart cards came in 1986 with the appearance of the first standard for these cards, ISO 7816/1. ${ }^{14} 1986$ also marked the decision by the French telecommunications authorities to use prepaid chip cards for public pay phones. A major renewal of the phone system was required at the time and with increasing concerns about vandalism and theft from coin pay phones, the smart card was expected to be a cost-effective alternative. Today, prepaid phone cards remain the largest application for chip cards. Chips vs. Magstripe Cards

The security of smart cards differs from that of magnetic stripe cards. Security 
features include both software and hardware controls. Software protection is based on data access control and the use of encryption techniques and the hardware protections included in the smart card during manufacture. Smart cards use encryption to carry out many tasks, including payment authorization.

It is important to remember that the final decision whether to allow completion of any transaction is made within the smart card's microprocessor. This is significantly different from a credit card and therefore, an on-line or off-line transaction is basically the same for a smart card. ${ }^{15}$ The security of the smart card is enhanced since the card never has to reveal the card owner's password to any external system. ${ }^{16}$

The enhanced security of chip cards is notable because the main application for magnetic stripe cards is financial cards. These cards have produced many new types of crime, mostly derived from the security pitfalls of magnetic stripe media. Although card fraud in the U.S. and Great Britain has been increasing steadily -- estimated in 1992 to have increased 25\% over the previous year -- France reported a decrease in card fraud of $5 \%$ in 1991 , even while card use increased $15 \%$. This decrease coincided with the implementation of chips in French financial cards. ${ }^{17}$

The life of a smart card is estimated to be approximately five years, compared with the relatively shorter two to three year life of a magnetic card. The manufacturing cost of multifunction smart cards is estimated at about $\$ 4.00$, while the single purpose card is estimated at about $\$ 2.00 .{ }^{18}$ (The cost for a magnetic stripe card is approximately 30 cents, making smart cards significantly more costly to issuers.)

Both magstripe and smart cards have found many uses as a prepaid card. The most common uses for prepaid cards today are for single-purpose transactions that require exact change or the use of coins. Telephone calls, highway tolls, and urban mass transit tickets are of small dollar value and are already using prepaid cards. For 
consumers, stored-value cards can be more convenient and physically easier to handle than coins and paper notes. ${ }^{19}$ Prepaid single purpose cards are not subject to any financial regulatory issues. They are no different than buying tokens in advance of the receipt of the good. Reloadable smart cards begin to complicate matters considerably, due to the regulations on credit and debit cards and the issuance of "private money." These issues will be addressed in Section III.

Finally, a prime advantage of chip cards over magnetic stripe cards is their increased functionality. The storage capabilities could allow for a medical smart card, containing that information that is vital to safe provision of medical care whether routine or emergency in nature.

Although memory capacity of smart cards is currently between 2 and 64 kilobytes, higher levels are planned for future smart cards. Withe even larger memory capabilities, applications appear to be limited only by the imagination.

An additional type of card, the optical or laser card, also has been used for some applications but only in Japan, and is not yet widely used elsewhere. An optical card has a non-erasable, write once read many (WORM) type of storage capability. The amount of storage memory available is quite large, up to 4 megabytes of data, and optical cards have a promising potential use in the health care field.

The table that follows summarizes the basic characteristics of the cards discussed above. 
TABLE 2:

\begin{tabular}{||c|c|c||}
\hline \multicolumn{2}{|c||}{ Important Aspects of Information Storage ${ }^{20}$} \\
\hline \hline Type of Card & Capacity & Security \\
\hline Phone Card & 10 bytes & None \\
\hline Plastic & 100 s of bytes & None \\
\hline Magnetic Stripe & 100 s of bytes & $\begin{array}{c}\text { Limited -- enciphering; } \\
\text { Data protection achieved by external } \\
\text { devices }\end{array}$ \\
\hline Smart Cards & \# of kilobytes & $\begin{array}{c}\text { Self protected units controlled by } \\
\text { microprocessor }\end{array}$ \\
\hline Optical Cards & Several megabytes & $\begin{array}{r}\text { Limited -- enciphering; } \\
\text { Data protection achieved by external devices }\end{array}$ \\
\hline \hline
\end{tabular}

\section{Pilot Stored-value Card Programs}

An untold number of single purpose stored-value card applications already are in place. More general, multiple purpose money card experiments, or trials, while less common, number at least 50 globally. According to the president of MasterCard International, Eugene Lockhart, "the reason for all of these pilot programs is that no one has yet proven the business case. l'll be really interested to see if anyone makes money out of this." ${ }^{21}$ It is true that no one has yet proven the business case for these new electronic money systems, but that has certainly not stopped the proliferation of pilot programs in the world. Pilot projects are currently underway in virtually all the developed countries of the world as well as several developing countries, such as China. The table at the end of this section was compiled for the Basle committee and shows only the major pilots underway in the G-10 countries. Appendix A looks at the largest card-based pilots that are currently underway or are planned for 1997. Parallel Development of other Electronic Money Schemes 
Other electronic money schemes are the network-based payment systems that are primarily being developed to allow more secure transactions to take place over the Internet. Although there are currently many variations of "value" that can be used over the Internet to buy items from electronic merchants, no final standard has yet been decided upon and no system seems to be totally without drawbacks of some sort. Merchants are betting that consumers are willing to buy goods and services over the Internet. Traditional means of making payments either will not work or have drawbacks when used on the Internet. Many transactions are likely to encounter problems of trust, security, or size ${ }^{22}$ as these transactions over the Internet are generally conducted by strangers unable to verify with whom they are doing business and even whether the business is a legitimate one. In addition, the small value of transactions, often pennies, makes traditional payment systems too costly to operate. Many companies are trying to develop secure methods of making payments in "cyberspace." There are two basic methods of protecting the security of payment information — value-added networks and encryption - and they may be employed separately or together. ${ }^{23}$

Value-Added Networks: A value-added network (VAN) to handle confidential data is more secure than sending plain text over a network that is open to anyone. Information that flows to the VAN from the open network must pass through "firewalls," which are computers programmed to allow only authorized transmissions to penetrate.

Encryption: Scrambling information before it is sent over an open network makes it more difficult for someone intercepting the transmissions to make use of the data. Encryption is estimated to be less costly than the value-added approach of operating a secure network. However, both parties to a transaction need to have compatible software as well as the keys to unscrambling the information. One of the most straight forward uses of encryption would be to incorporate it into the Web browsers, as 
companies such as Microsoft have attempted to do. ${ }^{24}$

Many different schemes have been devised to make purchases secure over the Internet, and every day there seems to be another report of yet one more attempt to "crack this market wide open." Early participants in this market, Cybercash and First Virtual, have not seemed to make the inroads that were predicted. Both of these models require a prior arrangement between the consumer and the merchant, limiting the potential transactions. These, however, are just two of the many variations that are available for those who want to make purchases over the Internet.

There have been some efforts to develop an industry wide security standard that would for secure payments information traveling on an open network. MasterCard and Visa agreed to develop the SET (Secure Electronic Transactions) standard to address consumer concerns. These early standards were published on the Internet in March 1996, with the expectation that this single standard would advance the effort to make conducting bank card transactions in cyberspace as secure and easy as in retail stores. $^{25}$

The companies involved in this project are MasterCard and Visa, GTE, IBM, Microsoft, Netscape, SAIC, Terisa Systems and Verisign. Also, SET will be based on specially designed encryption technology from RSA Data Security. ${ }^{26}$ Additional international cooperation on standard setting is underway, discussed in Section V.

There is also one other alternative that has not been mentioned. In late September 1996, Cybercash and Mondex announced that they planned to team up and that the Mondex card would soon be a payment option on the Internet. The two companies have agreed to integrate the stored-value technology of Mondex with the "virtual wallet" of Cybercash to make purchases or to transfer value. The technology is predicted to be available in mid-1997, but it could take far longer to get cards and 
readers into the hands of customers. ${ }^{27}$

TABLES

The tables on the next three pages list the major G-10 pilots involving both card based and network based systems. The data comes from a survey and was accurate in June of 1996. As you may note, this area is evolving so quickly it is difficult to keep up-to-date on all activities in this exciting new technology. 
Table 3: Electronic Money Schemes Operating and Pilots Planned in G-10 Countries

\begin{tabular}{|c|c|c|c|c|}
\hline Country & $\begin{array}{l}\text { Name of } \\
\text { Scheme }\end{array}$ & Type* & Type of Provider & Comments \\
\hline Belgium & Proton & $\mathrm{C}$ & $\begin{array}{l}\text { Joint company } \\
\text { (Banksys) set up by } \\
\text { major Belgium banks }\end{array}$ & $\begin{array}{l}\text { Pilot project in several towns; to be } \\
\text { extended nationwide by the end of } \\
\text { 1996; no purse-to-purse facilities }\end{array}$ \\
\hline \multirow[t]{4}{*}{ Canada } & UBI & C & $\begin{array}{l}\text { A consortium by a major } \\
\text { cable co.(Le Groupe } \\
\text { Videotron), a bank } \\
\text { (National Bank, Canada } \\
\text { Post, et al. }\end{array}$ & $\begin{array}{l}\text { Pilot project to begin in } 1996 \text { in a } \\
\text { region. }\end{array}$ \\
\hline & $\begin{array}{l}\text { Mondex } \\
\text { Canada }\end{array}$ & C & $\begin{array}{l}\text { Banks (CIBC, Royal } \\
\text { Bank, Hong Kong Bank } \\
\text { of Canada }\end{array}$ & $\begin{array}{l}\text { Pilot project begun in } 1996 \text { in } \\
\text { Guelph, Ontario. }\end{array}$ \\
\hline & Visa Canada & $\mathrm{C}$ & Banks & $\begin{array}{l}\text { Various test to be conducted in } \\
1996 .\end{array}$ \\
\hline & Mastercard & C & & \\
\hline France & $\mathrm{N} / \mathrm{A}$ & $\mathrm{C}$ & $\begin{array}{l}\text { Local communities. } \\
\text { A bank (Compagnie } \\
\text { Bancaire, groupe } \\
\text { PARIBAS) }\end{array}$ & $\begin{array}{l}\text { Many projects being considered. } \\
\text { A pilot scheme of an "electronic } \\
\text { shopping centre" on the Internet, } \\
\text { which includes the possibility of } \\
\text { traditional payments by bank cards } \\
\text { and, for low value payments, by } \\
\text { using a purchasing power reserve } \\
\text { previously constituted with the } \\
\text { system (virtual e-purse) }\end{array}$ \\
\hline Germany & $\begin{array}{l}\text { Geldkarte } \\
\text { Paycard }\end{array}$ & C & $\begin{array}{l}\text { The German banking } \\
\text { industry } \\
\text { Deutsche Telekon, } \\
\text { Deutsche Bahn AG and } \\
\text { regional transportation } \\
\text { operators }\end{array}$ & $\begin{array}{l}\text { Pilot project: to be operated } \\
\text { nationwide by the end of } 1996 \text {. } \\
\text { A card which will initially provide, in } \\
\text { addition to a telephone card, a } \\
\text { function for purchases of railway } \\
\text { and bus tickets: to be operated } \\
\text { nationwide by September } 1996 \text {. }\end{array}$ \\
\hline Italy & $\begin{array}{l}\text { Cassamat } \\
\text { Mini Pay- } \\
\text { SSB }\end{array}$ & C & $\begin{array}{l}\text { A federation of } \\
\text { cooperative credit } \\
\text { institutions (Raiffeisen) } \\
\text { Banks. }\end{array}$ & $\begin{array}{l}\text { A local multi-purpose prepaid card } \\
\text { scheme launched in some } \\
\text { provinces of Alto Adige in 1994; no } \\
\text { purse-to-purse transactions } \\
\text { envisaged. } \\
\text { Multi-purpose prepaid car project } \\
\text { which will be launched in Turin in } \\
\text { mid-1996; to be extended } \\
\text { nationwide in 1997; no purse-to- } \\
\text { purse transfers envisaged. }\end{array}$ \\
\hline Japan & $\mathrm{N} / \mathrm{A}$ & C & $\begin{array}{l}\text { Banks (e.g. Mitsubishi, } \\
\text { Fuji legally not providers } \\
\text { themselves, but leading } \\
\text { promoters }\end{array}$ & $\begin{array}{l}\text { Several pilot projects of card based } \\
\text { schemes have been launched } \\
\text { which can be used at limited sites } \\
\text { such as in an "intelligent building" } \\
\text { (e.g. Yokohama Landmark Tower). }\end{array}$ \\
\hline
\end{tabular}




\begin{tabular}{|c|c|c|c|c|}
\hline Netherlands & $\begin{array}{l}\text { Primeur } \\
\text { Card } \\
\text { Chipknip } \\
\text { Chippe } \\
\text { I-pay }\end{array}$ & C & $\begin{array}{l}\text { A non-bank institution } \\
\text { (Primeur Card BV) set } \\
\text { up by a number of } \\
\text { retailers. KPN (the Dutch } \\
\text { telecom org.) And } \\
\text { Achmea (includes bank } \\
\text { and insurance co.) have } \\
\text { announced participation } \\
\text { in the share capital. } \\
\text { Banks. } \\
\text { A joint venture of KPN } \\
\text { and Postbank (a major } \\
\text { Dutch bank). } \\
\text { Banks and KPN. }\end{array}$ & $\begin{array}{l}\text { Pilot projects in tow towns; no } \\
\text { purse-to-purse facilities. Primeur } \\
\text { Card BV is currently discussing with } \\
\text { the Netherlands Bank how to } \\
\text { comply with the Banking Act (i.e., } \\
\text { how to become authorized as a } \\
\text { credit institution). } \\
\text { Pilot program in one city; to be } \\
\text { extended nationwide in second half } \\
\text { of } 1996 \text {; no purse-to-purse transfer } \\
\text { facilties. Nonbanks will be able to } \\
\text { issue the card under licensing } \\
\text { agreements. } \\
\text { Nationwide introduction in the } \\
\text { second half of 1996; no purse-to- } \\
\text { purse transfer facilities. Nonbanks } \\
\text { will be able to issue the card under } \\
\text { licensing agreements. } \\
\text { Initially, this is a six month pilot } \\
\text { project permitting traditional } \\
\text { payments to be made through } \\
\text { Planet Internet (the largest Dutch } \\
\text { Internet provider) that will start } \\
\text { soon. At a later stage a pilot project } \\
\text { with an "electronic token" is } \\
\text { planned. }\end{array}$ \\
\hline Sweden & $\begin{array}{l}\text { N/A } \\
\text { N/A } \\
\text { Digicash }\end{array}$ & $\begin{array}{l}\mathrm{C} \\
\mathrm{C} \\
\mathrm{N}\end{array}$ & $\begin{array}{l}\text { A bank-related financial } \\
\text { company. } \\
\text { Banks (Sweedbank and } \\
\text { Nordbanken) } \\
\text { Swedish Post Office }\end{array}$ & $\begin{array}{l}\text { Pilot project in one city. } \\
\text { Introducing Proton on a pilot basis } \\
\text { in } 1996 . \\
\text { Preparing to introduce Digicash } \\
\text { during } 1996 .\end{array}$ \\
\hline Switzerland & Cash & C & $\begin{array}{l}\text { A joint company } \\
\text { (telekurs) owned by the } \\
\text { Swiss banks. }\end{array}$ & $\begin{array}{l}\text { Preparing to introduce a nationwide } \\
\text { prepaid card scheme adopting the } \\
\text { Belgian Proton technology. This } \\
\text { system is scheduled to be launched } \\
\text { on January } 1,1997 \text {. }\end{array}$ \\
\hline United Kingdom & Mondex & $\mathrm{C}$ & $\begin{array}{l}\text { Banks ( a co-venture } \\
\text { between Natwest and } \\
\text { Midland) }\end{array}$ & $\begin{array}{l}\text { Pilot project in Swindon (July 1995); } \\
\text { purse-to-purse facility available, but } \\
\text { on a restricted basis. Second pilot } \\
\text { at Exeter University (September } \\
\text { 1996) also on a restricted basis. }\end{array}$ \\
\hline
\end{tabular}




\begin{tabular}{|c|c|c|c|c|}
\hline United States & $\begin{array}{l}\text { Visa } \\
\text { Smartcash } \\
\\
\text { VisaCash/ } \\
\text { Mastercard } \\
\text { Mondex } \\
\\
\text { Digicash } \\
\text { Electronic } \\
\text { System }\end{array}$ & C & $\begin{array}{l}\text { Banks (First Union, } \\
\text { Wachovia, and } \\
\text { Nationsbank) } \\
\text { A joint venture by EPS, } \\
\text { owned by a group of US } \\
\text { bank holding companies } \\
\text { and the operator of the } \\
\text { MAC ATM Network. } \\
\text { Two banks (Citibank and } \\
\text { Chase). } \\
\text { Mark Twain Bank, St. } \\
\text { Louis, Missouri } \\
\text { Citibank }\end{array}$ & $\begin{array}{l}\text { The two banks in conjunction with } \\
\text { Visa Cash and MasterCard Mondex } \\
\text { have announced plans to launch a } \\
\text { pilot stored-value card program on } \\
\text { the Upper West Side of Manhattan } \\
\text { in New York City in late } 1997 . \\
\text { Mark Twain Bank began offering } \\
\text { Digicash to its customers in late } \\
\text { 1995. } \\
\text { Citibank has developed electronic } \\
\text { money technology, including } \\
\text { hardware and software, for use over } \\
\text { a communications network. No } \\
\text { pilot test of the technology has yet } \\
\text { been scheduled. }\end{array}$ \\
\hline
\end{tabular}

Source: Committee on Payment and Settlement Systems, Basel, 1996 (unpublished).

${ }^{\star} \mathrm{C}=$ Card based electronic money schemes.

$\mathrm{N}=$ Network based electronic money schemes.

Note: Only the major schemes and pilots are listed. 


\section{SECTION III. CURRENT REGULATORY ENVIRONMENT}

Government regulations often reflect more diverse interests than those of consumers, merchants and developers of transaction devices. ${ }^{28}$ Formulating regulations or passing legislation provides a policy constraint that can be useful in developing products whose complexities few individual consumers understand. Although Industry standards and technological constraints may change often, regulations and legislation can provide a more stable basis of understanding and trust in these complex products, as policy makers respond to future problematic situations..

Harnessing the chimera of electronic value is not going to be an easy task, especially on a global level. Understanding the regulatory environment is essential to entering the market with a successful venture.

\section{U.S. Current and Proposed Regulations}

In the United States, significant questions are being raised about regulations applicable to stored-value cards. Current regulations that might apply to stored-value cards or electronic value include Regulation E (Electronic Transfer liability limits) and Regulation Z (consumer protection concerns).

Regulation E was established by the Federal Reserve Board to implement the Electronic Funds Transfer Act of 1978. The regulation was designed to protect consumers and defined the rights and obligations of both consumers and "financial institutions" when electronic transactions affect consumer accounts. The term "financial institution" has been given a widely expansive definition by both legislation and the Federal Reserve Board. Therefore, many smart card issuers will be covered by the provisions of Regulation E.

Regulation $\mathrm{E}$ is important to the issuers of smart cards. It

- provides rules for the manner in which certain "access devices" such as 
debit cards, may be solicited and issued.

- establishes the conditions and terms of disclosure for providing these devices.

- requires documentation in the form of transaction receipts and periodic account statements.

- $\quad$ sets forth limitations on consumer liability (at present \$50).

- $\quad$ specifically details how consumer disputes will be resolved. ${ }^{29}$

The Federal Reserve has determined that stored-value cards are subject to Regulation E, but proposes to exempt a large class of applications from the full range of its rules. The proposal, published for comment in the Federal Register, would use a "light hand" in applying Regulation E consumer protection standards to smart cards and similar systems that can automate cash transactions. ${ }^{30}$ Table 4 shows how Regulation E would be applied to various types of stored-value cards.

As currently proposed, any stored-value card with a maximum value of $\$ 100$ would be exempt from Regulation E requirements. For cards with higher maximum values, further distinctions are based on the type of stored value delivery system. For stored value systems that are "off-line unaccountable" systems -- those that provide no immediate electronic authorization (authorization is based solely on the value contained on the card) and do not track individual transactions -- would be required only to provide initial disclosure to meet Regulation E requirements. ${ }^{31}$ For online systems -- those that have immediate electronic authorization and track individual transactions in a central database -- more rigorous requirements are proposed including provision of receipts and conformity with consumer liability limits.

On September 30, 1996, in the law recapitalizing the Savings Association Insurance Fund (SAIF), Congress instructed the Federal Reserve Board to wait at least 
nine months before deciding whether the consumer protections in Regulation E should be applied to stored-value products. The law also gives the Fed six months to study the effect of regulation on the development of stored-value and smart card systems. ${ }^{32}$

In a legal opinion issued in July 1996, the Federal Deposit Insurance Corporation (FDIC) said that most stored-value cards are not covered by deposit insurance. But the agency said that banks could devise cards that would qualify for FDIC coverage. These products would hold money in the customer's account, rather than stored on the card, until a payment was made, similar to a POS debit card. The agency requested public comment on whether there should be a regulation adopted to accompany the legal opinion. The comment period has ended and all commenters argued that regulating stored-value cards would stifle innovation. Most commenters also noted that consumers do not consider stored-value cards to be deposits or bank accounts, an interesting comment as most consumers have little knowledge of stored-value cards. However, bankers generally agreed that they should voluntarily disclose to consumers whether stored-value cards are federally insured. ${ }^{33}$

There are also a myriad of issues regarding escheat laws ${ }^{34}$, consumer protection laws, and privacy issues that must be addressed. 
Table 4: Currently Proposed Regulation E Requirements for Stored-Value Cards ${ }^{35}$

\begin{tabular}{|c|c|c|c|c|}
\hline & $\begin{array}{c}\text { Stored-value } \\
\text { Account not } \\
\text { greater than } \\
\$ 100.00\end{array}$ & $\begin{array}{c}\text { Off-line } \\
\text { unaccountable - } \\
\text { stored-value } \\
\text { systems }\end{array}$ & $\begin{array}{c}\text { Off-line } \\
\text { accountable } \\
\text { stored-value } \\
\text { systems }\end{array}$ & $\begin{array}{c}\text { On-line stored- } \\
\text { value systems }\end{array}$ \\
\hline $\begin{array}{c}\text { Prohibits } \\
\text { Issuance }\end{array}$ & No & No & Yes \\
\hline $\begin{array}{c}\text { Initial Disclosures } \\
\begin{array}{c}\text { Changes in } \\
\text { Terms Notice }\end{array}\end{array} \quad$ No & No & No & No & Yes \\
\hline Receipts & No & No & No & Yes \\
\hline $\begin{array}{c}\text { Periodic } \\
\text { Statements }\end{array}$ & No & No & No & No* \\
\hline Liability Limits & No & No & No & Yes \\
\hline $\begin{array}{c}\text { Error Resolution } \\
\text { Procedures }\end{array}$ & No & No & No & Yes \\
\hline $\begin{array}{c}\text { Annual Error } \\
\text { Resolution } \\
\text { Notices }\end{array}$ & No & No & No & No \\
\hline
\end{tabular}

*Balance and transaction history available on request. 


\section{Basel Committee and the G-10 ${ }^{36}$ Proposals}

In an attempt to work together and to standardize regulations and supervision of the issuers of stored-value, or electronic money, a Working Group on Electronic Money Provider ${ }^{37}$ Issues was established following the G-10 Governors discussion on electronic money in November 1995. The Working Group prepared a paper for the Committee on Payments and Settlement Systems (CPSS) of the Basel Committee that dealt with issues of risk, clearing and settlement, competition and consumer protection. ${ }^{38}$ Other groups were requested to provide papers on other issues of interest to the Committee, including seigniorage, law enforcement, and security.

Currently four classes of institutions are considered to be potential issuers of "smart cards" or other forms of electronic money. These four groups are generally assumed to be central banks (and other official bodies, such as the Department of Treasury in the United States), banks/credit institutions, other supervised financial institutions, and non-financial institutions (currently not subject to financial regulation/supervision). In each of these classes of issuers there are policy concerns that need to be addressed. The three major areas requiring policy considerations are 1) the financial integrity of issuers and potential systemic consequences, 2) clearing and settlement issues, and 3) competition and consumer protection.

\section{Risk Issues}

If the issuer of the stored-value instrument is a central bank or other official body, credit risk would not be considered an issue as the electronic value of money would have a status similar to that of cash, a risk free liability of the state. Although there may remain a technical risk ${ }^{39}$, a central bank would be able to support its electronic money scheme without undermining public confidence in the payment media. Stored-value issued by a private institution might not have equivalent financial integrity, but if the 
value were collateralized by short-term government securities it would be closer in terms of credit risk to the central bank obligations. If the stored-value were backed by investments in riskier or less liquid assets, holders and acceptors of the stored-value would be exposed to both credit and liquidity risk.

Typically, credit institutions are subject to government supervision that attempts to control risk of illiquidity or insolvency. In return, those institutions are eligible for direct liquidity support by central banks. Any risk that a credit institution would not be able to meet its stored-value obligations is thereby minimized. In the case of supervised financial institutions that are not banks, the financial integrity of the issuer depends on the scope and quality of the supervision in the home country. There is considerable debate as to whether a supervised financial institution that is not a bank could be just as safe, or even safer, if the stored-value was backed by high quality assets. But, once again the issue of lack of access to the central bank for liquidity assistance could be considered a factor in determining whether these institutions should be permitted to issue stored-value instruments.

One model for nonbank electronic money schemes is the treatment of money market mutual funds that allow check writing privileges. Regulations and liquidity requirements that are associated with these nonbank instruments by supervised financial institutions bear examination. Similar restrictions could be used to ameliorate the risks that are perceived in this type of institution when offering electronic money transfer products.

Major concerns come into play with the non-financial entities, for currently there is no regulatory oversight of management of funds received against the issue of storedvalue. Although market forces might provide the issuer with a commercial incentive for safe investment of the funds, incentives may not be sufficiently strong to meet possible 
central bank concerns.

Currently, none of the G-10 countries has any specific legislation governing electronic money. Japan's Prepaid Card Law addresses one important aspect of electronic money by mandating that an issuer maintain deposits of cash or eligible securities amounting to $50 \%$ of the unused balances of all cards.

In the European Union countries, following publication of an EMI report in 1994, a consensus on a regulatory framework has begun to emerge. Providers of multipurpose pre-paid cards must have the status of a credit institution as defined by the relevant banking law, and be regulated.

Clearing and Settlement Issues

Another policy issue that needs to be addressed is the clearing and settlement of funds. No matter what scheme is ultimately adopted, there will be multiple issuers and multiple acquirers, requiring a means of settlement. Methods and timetables will have an impact on any potential risks. Existing clearing and settlement systems would most likely be used to settle stored-value obligations between issuers and acquirers, but delays or other problems with counterparties could cause exposures for other issuers. Most of the current clearing and settlement systems restrict direct access to banks, so non-banks can only participate through a bank member.

Products with card to card transfer capabilities raise the potential for the obligations between major electronic money participants to be settled outside of the traditional interbank clearing and settlement channels. ${ }^{40}$ This is not necessarily a problem as long as the liquidity of the institutions is not threatened and the obligations can be met.

The third major issue deals with competition and consumer protection. Although competition is assumed to bring benefits in terms of reduced costs and improved 
services to consumers, if the central banks were to issue electronic money consumers would not be exposed to credit risk. If there were a wide variety of electronic money products that had been issued by different types of institutions, unsophisticated consumers could be confused regarding the risks and advantages of each product. This has happened recently with prepaid phone cards and there have been a number of companies that have sold these cards and subsequently gone out of business before the balances are extinguished. However, this is really no different than multiple issuers of credit cards and the proliferation of brand names for all consumer products.

In the near term, it is assumed that banks will not be the dominant providers and issuers of stored-value products with more limited uses, i.e, subway, telephone, campus cards. However, the electronic purse type stored-value card is expected to be issued by financial institutions. A theoretical extreme would have the central banks issuing all electronic value, but this has not been proposed with any seriousness. The 1994 EMI report recommended that only credit institutions should be issuing electronic money, but there is no consensus among the G-10 countries regarding who should be allowed to issue electronic money, as noted in the table at the end of this section.

In many countries, consumer protection ${ }^{41}$ is not a responsibility or primary concern of the central bank. It is also not clear whether supervisory authorities will consider stored-value products eligible for deposit guarantee or insurance arrangements, or institute other means to safeguard customer funds.

The key potential risks of electronic money schemes as viewed by the central banks fall into four areas. Each will be defined and discussed separately and then the policy implications will be addressed.

Financial Integrity of the Issuer: The financial integrity of financial institutions is a primary concern of central banks and other supervisory authorities is. This concern 
falls into separate categories as they relate to the direct impact of a failure of a financial institution and the other effects on third parties.

The major concern regarding financial integrity in relation to issuers of electronic money is the prudent management of the assets held in exchange of electronic value. Central banks are concerned that institutions that take deposits behave prudently, and are thus able to redeem such funds on demand. Issuing electronic money resembles deposit-taking so that standards similar to those applied to deposit-taking might be applied to electronic money schemes. Alternatively, as long as outstanding amounts remain small, these standards could impose unnecessary costs and therefore inhibit the diffusion of this form of payments mechanism. Again, money market mutual funds could be used as a model for setting regulations that protect the consumer without unduly burdening the issuer.

The type of entity that issues the electronic money may have far-reaching implications for the financial integrity of the system. Assuming that initially, most electronic money will be issued by banks suggests that consumer confidence in the product will be high, promoting its acceptability. However, large non-financial institutions are expected to enter this market, especially telecommunications and computer companies and are currently not subject to the same regulations as banks. It is important to determine if electronic money issued by this type of institution would be treated any differently than money issued by a bank. And this becomes a very touchy issue for regulators and policy makers.

Integrity of the instrument: There is considerable regulatory concern about counterfeiting, fraud and other criminal aspects that might cause the default of an issuer. " 'Forgery' of electronic money would involve the introduction into the system of electronic value for which no corresponding payment has been made." 42 This could 
result from either an outside attack or inside conspiracy, but in both cases the issuer would not receive the corresponding assets for the fraudulent value.

Other aspects of electronic money lend themselves to criminal activities and purposes, including tax evasion and money laundering. If an electronic money device is offered without any relationship to a bank account, or is capable of card-to-card transfers, money laundering issues could arise.

These issues are not entirely unique to electronic money, but they do provide new twists that need to be considered. Counterfeiting of money, no matter what the form, has always been a concern. In addition, the use of cash allows anonymity which is not available with other paper- and electronic-based forms of payment. These concerns regarding electronic money need to be considered and thought given to how to address potential problems and issues.

Systemic considerations: Resiliancy of the payments system can help to prevent problems in one sector of the payments mechanism from having a far-reaching effect on other sectors of the system. If one institution involved in an electronic money scheme failed, it could have serious ramifications on others that have claims against it. Also, the public confidence in other electronic money schemes could be damaged, and that confidence could spread to other retail payments systems.

If electronic money became so widely used that there was no alternative means of making payments, for example the Metro system in Washington or vending machines that had been converted to accept only stored-value cards, the chances of systemic risk permeating the system could increase dramatically. However, this is not likely to be the case in the foreseeable future.

The results of an electronic money issuer failing would depend on the amount of 
value issued and the circumstances surrounding the failure of the institution. As electronic money became more widely used, systemic risk has the potential to increase. However, if the Central banks did not guarantee the issuers of electronic money, market forces should force private entities to monitor each other and set up appropriate risk controls.

Efficiency and social benefits: "Electronic money products and innovations generally have the potential to bring new cost-effective electronic payment methods to consumers, particularly in countries where automation of paper-based payments has proved challenging." ${ }^{43}$ Generally, the purpose statements of Central banks note that promoting efficiency in both the financial system and the payments system, in particular, are primary responsibilities.

Developers of electronic money products constantly promote the schemes as having the advantages of convenience for consumers and cost savings for retailers and issuers. However, the benefits offered by any particular scheme will depend on the ease and scope with which it may be used by consumers and retailers. The general view is that Central banks should not seek to inhibit development of electronic money, and that an appropriate regulatory framework should take into account potential social benefits as well as risks. 


\section{Table 5: Regulatory Structure for electronic money in G-10 countries}

\begin{tabular}{|c|c|c|c|c|}
\hline \multirow[t]{2}{*}{ Country } & \multicolumn{2}{|c|}{ Current Structure } & \multicolumn{2}{|c|}{ Proposed Structure } \\
\hline & $\begin{array}{l}\text { Specific legislation, } \\
\text { if not, what covers } \\
\text { it? }\end{array}$ & $\begin{array}{l}\text { Who is allowed to } \\
\text { issue elec money? }\end{array}$ & $\begin{array}{l}\text { Do you envisage legislative } \\
\text { changes? }\end{array}$ & $\begin{array}{l}\text { Then, who would be able to } \\
\text { issue elec money? }\end{array}$ \\
\hline Belgium & $\begin{array}{l}\text { None; the current } \\
\text { Banking Act }\end{array}$ & $\begin{array}{l}\text { Credit institutions } \\
\text { (de facto) }\end{array}$ & None at this time. & $\begin{array}{l}\text { Credit institutions } \\
\text { (de facto) }\end{array}$ \\
\hline Canada & None; not evident. & No restrictions & Under discussion. & Not Answered \\
\hline France & $\begin{array}{l}\text { None; the current } \\
\text { Banking Act }\end{array}$ & Credit institutions & None at this time. & Credit institutions \\
\hline Germany & None; not evident. & No restrictions & $\begin{array}{l}\text { The Banking Act will be amended } \\
\text { in order to make issuance of } \\
\text { prepaid cards (except single } \\
\text { purpose prepaid cards) banking } \\
\text { business. }\end{array}$ & $\begin{array}{l}\text { Credit institutions subject to } \\
\text { full supervisory requirements } \\
\text { for multi-purpose prepaid cards } \\
\text { (representing generally } \\
\text { accepted purchasing power). } \\
\text { Providers of smaller card } \\
\text { systems would be exempted } \\
\text { from a number of requirements. }\end{array}$ \\
\hline Italy & $\begin{array}{l}\text { None; the current } \\
\text { Banking Act }\end{array}$ & $\begin{array}{l}\text { Credit institutions } \\
\text { (multi-purpose } \\
\text { prepaid cards) }\end{array}$ & None at this time. & Credit institutions. \\
\hline Japan & $\begin{array}{l}\text { No comprehensive } \\
\text { law; existing } \\
\text { "Prepaid Card Law" } \\
\text { might apply }\end{array}$ & $\begin{array}{l}\text { No restrictions } \\
\text { (Legal opinion has } \\
\text { not been } \\
\text { established). }\end{array}$ & None at this time. & Not Answered \\
\hline $\begin{array}{l}\text { Netherland } \\
\mathrm{s}\end{array}$ & $\begin{array}{l}\text { None; the current } \\
\text { Banking Act }\end{array}$ & $\begin{array}{l}\text {-multi-purpose } \\
\text { prepaid cards: credit } \\
\text { institutions. } \\
\text {-network-based } \\
\text { schemes: credit } \\
\text { institutions * }\end{array}$ & None at this time. & Credit institutions. \\
\hline Sweden & None; not evident & No restrictions & $\begin{array}{l}\text { Under discussion; Banking Law } \\
\text { will be amended }\end{array}$ & $\begin{array}{l}\text { Probably, credit institutions in } \\
\text { accordance with the } \\
1994 \text { EMI Report }\end{array}$ \\
\hline Switzerland & None; not evident & No restrictions & $\begin{array}{l}\text { Total revision of Swiss Federal } \\
\text { Constitution may lead to some } \\
\text { amendments to Swiss monetary } \\
\text { system, including electronic } \\
\text { money. }\end{array}$ & Not Answered \\
\hline $\begin{array}{l}\text { United } \\
\text { Kingdom }\end{array}$ & None; not evident & $\begin{array}{l}\text { Depends on } \\
\text { features of scheme; } \\
\text { deposit or not? }\end{array}$ & $\begin{array}{l}\text { Will be determined; } \\
\text { Appropriateness of situation and } \\
\text { legal provisions governing such } \\
\text { activities will continue to be } \\
\text { monitored. }\end{array}$ & Not Answered \\
\hline $\begin{array}{l}\text { United } \\
\text { States }\end{array}$ & $\begin{array}{l}\text { None; relevant } \\
\text { federal and state } \\
\text { laws might apply }\end{array}$ & $\begin{array}{l}\text { Depends on legal } \\
\text { interpretation }\end{array}$ & $\begin{array}{l}\text { No specific recommended for } \\
\text { legislation (Fed Reserve) }\end{array}$ & Not Answered \\
\hline
\end{tabular}

${ }^{*}$ Netherlands Bank's preliminary view; legal opinion is currently being sought.

SOURCE: BIS Working Group on Provider Issues Relating to Electronic Money of the Committee on Payment and Settlement Systems (Preliminary Report, Unpublished) June 1996. 


\section{SECTION IV. DESIGN ISSUES}

"Two Firms to Promote Contactless Smart Cards,"

"French Smartcard Proves A Bright Idea," 45

"Visa Launches multi-function smart cards," 46

"Smartcards: a technology whose time has come" 47

"MasterCard Hopes to Use Mondex Platform in Smartcard" 48

Such headlines as these of the business press daily proclaim the changing landscape of the electronic money field. Keeping track of whom has bought whom has become a full time job. And just when you think that you have the players straight, someone like American Express comes out of their corner and licenses a different technology!

And just as often the headlines shriek about potential security risks associated with the cards.

"Smart Cards Are Open to New Attack by Hackers, Say Israeli Researchers,", 49 "Cyberbanking: Risks on the New Frontier,"

"Smart Card Execs Question Report on Breachability." 51

When you get to the finer print, what most of these articles say can be summarized by Ronald Rivest, a professor at the Massachusetts Institute of Technology, when he states that although the report of the cards' vulnerability could take some of the shine off their image, adoption of the cards is not expected to be affected. He predicted few breaches of the cards' security because of the sophisticated understanding of cryptography required..$^{52}$

Bellcore, the research laboratory of Lucent Technologies, concluded early in October that "hypothetically", a smart card's chip could be made to malfunction and give 
mathematical clues to the secret keys and digital signatures that are the basis of its security. ${ }^{53}$ As no system is $100 \%$ foolproof, companies are constantly working with any number of players worldwide and industry-wide to ensure that cards, terminals, and other systems are one step ahead of the counterfeiters. ${ }^{54}$

Furthermore, the headlines above apply only to stored-value cards. There is another passel of headlines dealing with changes in the Internet-based systems. And in that instance a whole new "cyber-babble" has developed...the language of the Cyber-initiated that can only be understood once you have experienced the world of Cybercash, e-cash, Digicash, and First Virtual! And although the terminology may seem difficult to understand at first, there are really only a few major difference between the various types of offerings.

In most cases, network-based systems come in the two basic flavors that were discussed before - value-added-network based and encryption based. Although there are variations in the encryption methodology (public key versus private key), systems that attempt to replicate specie and those that are credit card based, they are all trying to do the same thing. They want to be the first to capture the hearts and pocketbooks of consumers who want to make secure purchases over an open network, where hackers are known to abound.

And for the value-added network based systems, the "firewalls" are constructed with slightly different hardware and software configurations, but again, they are trying to create a safe and secure environment for financial transactions in an unsafe world.

Now, this is not as simple as it sounds and the development of this technology has occurred over the last several decades. One estimate of the computer time required to "break" an RSA public key that is typically 200 digits long is $70,000,000$ 
MIPS-years — and even with increasingly faster machines, the keys are only lengthened by the provider of the public key. ${ }^{55}$

Standards are being developed for the security of internet purchases on both a nationwide and worldwide basis by several different groups. One can only hope that the various groups are discussing the standards with each other and will come up with one standard, rather than two competing ones. This cooperative effort is discussed further in Section V.

As with any new product, there are phases of technological development, and although the pioneers are generally the recipients of the initial cash flows, there is always the possibility of an upstart capturing the lion's share of the market. It is generally assumed that Mondex could become the prevailing technology, as they are farther ahead in bringing an actual product to the market, at least in this country. But, any industrial historian can tell you that the first to market is not necessarily always going to be the market leader in the long run. One need only look at the Beta versus VHS format in videocassettes, or the MAC versus Windows operating systems in personal computers to find examples of the early market leader being replaced by what many technicians considered inferior designs.

Citibank, in addition to being involved in the New York trial with Visa and MasterCard, has patented its Electronic Money System (EMS) that some experts believe not only rivals the Mondex system, but actually surpasses it in terms of capabilities and functionality. ${ }^{56}$

In April 1994, Citibank applied for a patent for EMS, which differs from the Mondex and other electronic cash systems in that it is designed to work on a computer network, and thus allows secure, immediate transfers of cash. Its cards can be inserted 
into personal computers and the cards contain their own tamper-proof security and transaction-processing software. ${ }^{57}$ Another distinguishing feature of EMS, is that unlike Mondex, it allows banks to keep track of the money that they are issuing. "As users fill their electronic wallets with cash, either by drawing down an existing balance or by borrowing, the bank creates digital banknotes that then travel around the electronic economy, splitting into smaller denominations as people spend their cash. Each note carries with it an electronic tag that allows the issuing bank to identify its money (although not necessarily to know who is using it)." ${ }^{58}$ There is also a version of EMS that provides a secure means of paying for goods and services on the Internet. It can handle any number of foreign currencies and exchange them at an agreed upon rate, which opens that market to corporate users as well as banks.

There are basically two different schemes for the provision of electronic money. The EMS system is similar to those being employed in several European countries at this time, specifically those in Finland, Denmark, Belgium, and Portugal. These systems are considered to be fully accounted schemes, while Mondex is a very comprehensive unaccounted scheme..$^{59}$ A schematic design of the two approaches is presented in Appendix C.

The best way to think of the difference is that in an accounted scheme, the smart card does not act as a universal cash replacement, but as an added payments medium for low value cash transactions. With cash there can be significant anonymity between the payor and the payee, and an accountable stored-value card does not ensure that level of anonymity.

The unaccountable scheme has a fundamental difference that is manifested in the ability for transfers between individual smart cards of monetary value to occur, 
essentially creating an unauditable transfer -- not very different from an exchange of paper money. This is different from a cash payment between parties, however, as it essentially creates a form of private money. And this is where the policymakers begin to wonder about regulation, safety and soundness, and who should be able to issue this value.

In essence, the basic design of the electronic money system put the creation of value into the realm of the private rather than the public sector. In an unaccounted scheme, the location of the money may never be fully known until the cards are redeemed for value. Therefore, they function just as cash. And although there will be requirements for the issuers to back the value with cash or some other form of liquid investments, at this time only regulated issuers will have a watch dog agency overseeing that they have sufficient value for redemption of the stored-value cards' worth. This does not need to be the case however, as a nonbank issuer could be subject to supervision and routine solvency testing by any number of government entities.

And this is where the policymakers and regulators get real nervous. If an unregulated entity issues stored-value cards and does not have the wherewithal to redeem that at some future date, what form of consumer protection is needed? If someone dies with value on a stored-value card, is the value considered an asset of the estate? How do the escheatment laws work in relationship to unredeemed value?

This unredeemed value is an issue for a number of reasons, but one especially stands out. There is a burgeoning collectible disposable stored-value card market developing, with some cards being worth hundred of times the face value of the card. As this is really the first new form of "money" created in recent memory, the market 
developed very quickly as collectors rushed to buy and not use specialty stored-value cards. That was one of the most surprising aspects of the Olympics trials for the banks involved. Many people never redeemed their value and used the cards as souvenirs. 


\section{SECTION V. DEEPER INTEGRATION ISSUES}

There are no current restrictions in the G-10 countries regarding the issuance of electronic money by foreign providers or electronic money schemes that are available in multiple currencies or foreign currencies. This is similar to the provision of foreign currency travelers checks.

In an EU country, an issuer will probably be required to be a credit institution under the relevant host country definition. ${ }^{60}$ It is assumed that the EU Second Banking Coordination Directive and Investment Service Directive would apply to foreign providers issuing electronic money in other EU member states as long as the issuer was established as a credit institution under the relevant legislation of the home EU country. One exception is Germany where there is a possibility that applicable German regulations would be applied to a foreign provider.

In the non-EU countries, there is no special legal or regulatory framework developed yet for foreign providers. There is one possible concern regarding multicurrency or foreign currency issuance. Japan's Foreign Exchange and Foreign Trade Control Law could be an impediment to the issuance of these types of electronic money.

Cross-border issues mainly revolve around the cross-border issuance of electronic money at this time. These issues need to be explored as the potential for conflicting regulations and legislation are likely to cause problems in this area unless they are addressed pro-actively.

Of major concern are the legal uncertainties regarding potential insolvency of a foreign issuer where there were financial claims held against providers that are based in foreign jurisdictions. ${ }^{61}$ Different countries assign different rights to creditors in the event 
that the issuer defaults and rules for unwinding a failed business may discriminate against foreigners. ${ }^{62}$

Cross border electronic money transactions via computer networks pose more problems in terms of regulation and supervision, and may also pose problems relating to practical enforcement of laws and regulations and fraud.

No Central bank has announced plans to issue electronic money at this time, with the exception of electronic benefits cards for welfare recipients in the United States and the potential issuing of similar types of cards in Canada. This is important as in most countries, the settlement and clearing infrastructure still remains, at least partially, in the domain of the government or Central bank. And this would be a logical place for this type of money to be developed.

Cooperation between the G-10 countries, at least on enumerating issues and concerns has been substantial, considering that there are few of these electronic money schemes which have been moved from the limited pilot to partial or full implementation. A pro-active stance on standardizing regulations has been proposed by the $\mathrm{G}-10$ countries.

Two international industry-wide groups have been formed to develop standards and address concerns and recommend solutions in the field of electronic money, one addressing the stored-value cards, the Smart Card Forum, and the other addressing standards for the network-based systems, the Joint Electronic Payments Initiative (JEPI).

Joint Electronic Payments Initiative (JEPI)

Earlier in this paper there was a discussion of the SET (Secure Electronic 
Transaction) standard that was being developed for use over the Internet. JEPI is a "super consortium" made up of Commercenet and W3C ( the World Wide Web Consortium associated with the Massachusetts Institute of Technology) that will promote payments over the Internet. With IBM, Microsoft, and Netscape, the members are providing or experimenting with new payments mechanisms,. There are seven "core participants" who have committed staff time and money and plan to have trials in 1996. The seven core members are Cybercash, the Financial Services Technology Consortium, GC Tech, IBM, Microsoft, Open Market, and Open Software Foundation. Other companies involved in the original group formed in April 1996 include BellCore, British Telecom, Citibank, First Virtual Holdings, Carnegie Mellon's NetBill program, Oracle, NTT of Japan, and Nokia. ${ }^{63}$ JEPI's challenge is to make sure on-line merchants are capable of accepting the types of payments consumers want to use.

In November 1996, members have agreed that corporate motives have slowed the collective process. But members have managed to develop a method for negotiating payments over the Internet. It is even expected that MasterCard and visa will embrace the standard. The trial for JEPI will incorporate the card associations' SET protocol.

The plan is to include more international players, especially Keio University in Tokyo and other Asian and domestic partners. This will probably increase the logistical difficulties, but will add the global reach that is desirable. ${ }^{64}$

Historically, other groups and other consortiums have developed standards and protocols only to find that "when they are done, nobody wanted to implement them....if some market-leading vendors - Microsoft, et al. — manage to pull something together more quickly and implement them on all the servers, the work of JEPI may end up for 
nought," states Victor Wheatman, a Gartner Group electronic commerce analyst. ${ }^{65}$

\section{TABLE 6}

\section{The Joint Electronic Payment Initiative ${ }^{66}$}

\section{Formed}

April 1996, by Commercenet and MIT's World Wide Web Consortium (W3C)

\section{Goals}

To create a standard negotiation protocol for Internet shopping, and to gain industry acceptance for it

\section{Core members}

Cybercash, Financial Services Technology Consortium, GC Tech, IBM, Microsoft, Open Market, Open Software Foundation, and Verifone

\section{Other Participants}

Bellcore, British Telecom, Citicorp, CUC International, Deloitte \& Touche Consulting, First Virtual, France Telecom, Marshall Industries, National automated Clearing House Association, NetBill(Carnegie Mellon University), NTT Software Laboratories, Nokia, Novell, Oracle, Sligos, Tandem, University of Souther California, Vendamall, and Zenith Data System

\section{Smart Card Forum}

The primary industry-wide group that is addressing the issues of stored-value card technology is the Smart Card Forum. Established in 1993 by Citicorp, BellCore, and the U.S. Treasury Financial Management Services Division to accelerate the widespread acceptance of smart cards that support multiple applications in North America. The concept was to bring together, in an open environment, the leading business and technology executives from the public and private sector to promote interoperability across applications and technologies and to facilitate market trials. ${ }^{67}$

Membership in the Forum has grown rapidly to over 230 corporate and government entities from the U.S., Canada, South America and Europe. Education, business development, and public policy initiatives have become additional goals of the forum.

The reasons that the Smart Card Forum feels that interest has been so great are 
listed below.

- Covergence of information technologies is creating new business opportunities spurred by electronic delivery.

- Increase competition, from non-traditional industry players as boundaries between information and payment technologies blur, is causing traditional providers of these services to look for ways to enhance and retain customer relationships.

- Costs of smart cards and readers are declining as functionality and capabilities increase. Enhancements to card security, processing power, and storage create opportunties for multiple application cards.

- Regulatory bodies are increasingly concerned about consumer issues related to stored value and healthcare information cards.

- International standards for payments and telecommunications are emerging to eliminate the risks of interoperability.

- Growth of pilot projects worldwide for stored value, loyalty, college, and security applications is making smart car investments a reality, not a future event. ${ }^{68}$

One other group that is involved in smart card technology has also joined forces to develop an industry standard for smart card usage with personal computers for network access, Internet access, and payments. A number of top smart card and computer companies including Microsoft Corporation, Schlumberger Electronic Transactions, Hewlett-Packard Co., Bull CP8, and Nixdorf Informationsionsystems AG, have agreed to provide the protocol to the industry for free. ${ }^{69}$ 


\section{CONCLUSIONS}

There is much interest in these new form of payments being shown by technology firms, banking organizations, credit card companies, and Central banks. However, the majority of the general public is blissfully unaware that these new payments methods could be looming on the personal financial horizon. This poses a familiar problem for institutions investing in these technologies and anticipating rapid diffusion through society.

Banks are interested in these new electronic money schemes as a means to provide a portfolio of products to their customers and thus, maintain deposits. They anticipate the potential for cost savings from reduced cash handling costs as merchants accept the cards for purchases. They see an even more lucrative opportunity as stored-value cards are accepted at locations nationwide. The float that will result from transferring money to the cards at one time, and the payment to the accounts of the merchants who accept the cards at a later time, is also a valuable incentive. In addition, because stored-value cards use the computer chips stored in their memory, card readers for these transactions do not have to be connected to telephone lines, making the transactions faster and cheaper than using credit cards and possible in more locations. This convenience feature for both customers and merchants will need to be exploited, especially in small purchases, generally considered being those less than $\$ 20.00$.

Central banks are interested in electronic money schemes for a variety of reasons. The integrity of their currencies is important to them and these schemes might have some potential of undermining that integrity. The loss of seigniorage is also a minor concern. With the proper regulations in place, these cards should provide 
minimal risks. There is considerable coordination occurring on a national and international basis regarding electronic money systems. However, the legal and regulatory framework of these systems is still an issue across the world. In addition, there is no format or forum for dispute resolution regarding payment and settlement.

To address the issue of dispute resolution, an international body similar to the European Central Bank could be set up as a tribunal, made up of rotating representatives from the G-11 Central Banks and Security and Exchange Commissiontype organizations as a starting point. If the limitation is widely accepted that only credit institutions can issue electronic money, supervision of issuers will be easier than if there are no restrictions on who can issue electronic money. There is no working blueprint for setting up this type of organization and there would need to be escape clauses and other safeguards associated with any forum that is set up to handle the issues that might arise. On the other hand, too many escape clauses and safeguards could allow countries to get out, if the going got tough.

Without world-wide financial institution and governmental support for product standards and regulations these new electronic money instruments could continue to be only an adjunct payment method rather than a serious replacement for cash.

Today's payments system is a complex set of instruments, processing infrastructures, laws, rules and regulations, and institutions. Tomorrow's systems will provide more choices, be more high tech and become more complex. They will be a challenge for a policymakers who must walk a fine line between providing safety and stifling innovation. ${ }^{70}$

The next years will be exciting as these new systems emerge, evolve, and possibly even take hold. As stated by Jean McKenna, President of the smart Card 
Forum, "The impact will be revolutionary, widespread, and positive-- ${ }^{71 "}$. We shall see...... 


\section{ENDNOTES}

1. The term electronic money is often used to refer to a variety of retail payment systems. The electronic value is purchased by the consumer and is reduced whenever the consumer uses the devise to make a purchase. The definition covers both prepaid cards and prepaid software products that use a network such as the Internet. Prepaid cards are sometimes referred to as "electronic purses", while prepaid software is sometimes referred to as "digital cash".

2. "Cash -- Choice form of Payments", Business Week, April 8, 1996, p. 24.

3. This survey was conducted under the auspices of the Federal Reserve System. Questions were asked in the University of Michigan Survey of Consumers in May 1995 regarding the uses of currency and other payment methods. The University of Michigan Consumer Survey is conducted by the Survey Research Center, a unit of the Institute for Social Research at the University of Michigan, and is an ongoing monthly nationally representative survey based on telephone interviews of adults living in the coterminous United States (48 states plus the District of Columbia).

4.Congress of the United States, Congressional Budget Office,"Emerging Electronic Methods for Making Retail Payments", Washington, D.C., June 1996, p. ix.

5.Ibid.

6.Kutler, Jeffrey, "Challenging MasterCard, Visa Plans Java-based Alternative to Mondex", American Banker, March 26, 1997, p.1, vol. 162, no.58.

7. Bright, R., Smart Cards: Principles, Practices, Applications, Halstead Press, New York, 1988, p. 33.

8. Stuber, p. 3.

9. Zoreda and Oton, p. 36 .

10. All Japanese manufactured cards are under license from the Arimura Technology Institute even today.

11. Zoreda and Oton, p. 37.

12. Ibid, p. 37.

13. In 1992, French banks had issued more than 21 million smart cards, more than any other country.

14. Ibid, p.38.

15. Ibid, p. 43.

16. Stuber, p. 4.

17. Zoreda and Oton, p. 20.

18. Giannone, J.A. and Jarman, A., "Visa's Chip Card Strategy", Electronic Payments International, IV (April), p 4. 
19. Lacker, Jeffrey M., "Stored Value Cards: Costly Private Substitutes for Government Currency", Federal Reserve Bank of Richmond, (Due to be published, Summer 1996), April 8, 1996, p. 3.

20. Zoreda \& Oton, p. 3-25.

21.Graham, George, "World tries a new way to pay, " Financial Times, November 8, 1996, p.1.

22. Bauer, Paul W., "Making Payments in Cyberspace", Economic Commentary, Federal Reserve Bank of Cleveland, October 1, 1995, p.1.

23.Ibid, p. 2.

24.Ibid, p.2.

25.MasterCard International Press Release, "Visa \& MasterCard Combine Secure Specifications For Card Transactions On The Internet Into One Standard", http://www.mastercard.com, February 1, 1996.

26.Ibid.

27. Block, Valerie, "Cybercash, Mondex Team Up To Put Smart Card on the Web,"American Banker, Vol. 161, no. 186, On-line Edition.

28.Bucciarelli, Louis L., Designing Engineers, MIT Press, Cambridge, Massachusetts, 1996, p. 132.

29. Allen, Catherine and Barr, William J., editors, Smart Cards, Seizing Strategic Business Opportunities, Irwin Professional Publishing, Chicago, 1996, p. 70-73.

30.deSenerpont-Domis, Olaf, "For Stored Value Cards, the Fed Proposes Light Consumer Regs", American Banker, March 21, 1996, p.1.

31. Allen and Barr, p. 71 and Federal Reserve Board of Governors, "Official Staff Commentary on Regulation E Electronic Funds Transfer (As amended May 2, 1996)", Washington, D.C., August 1996, pp. $1-21$.

32.Rehm, Barbara A., "Not Just SAIF, But a Potpourri Affecting Banks", American Banker, Vol 161, no. 189, October 2, 1996, Online Edition.

33.deSenrpont Domis, Olaf, "Capital Briefs: Regulation of Stored-Value Cards Opposed", American Banker, Vol. 161, No. 223, November 20, 1996, On-line Edition.

34.Escheat laws deal with the right of the state to take title to property after the death of a person who has not disposed of the property by will and has left no heirs to inherit it. The laws vary from state to state.

35. Ibid, p. 73 (Allen and Barr).

36. The G-10 countries are 11 in number and include Belgium, Canada, France, Germany, Italy, Japan, Netherlands, Sweden, Switzerland, United Kingdom, and United States.

37. Provider and issuer are used interchangeably.

38. "Electronic Money: Provider Issues and Regulatory Structure", Report by the Working Group on Provider Issues Relating to Electronic Money of the Committee on Payment and Settlement Systems, 
Basel, June 1996 (Preliminary, Unpublished), p. 1.

39. Technical risk is the risk that technological innovation will exceed the capabilties of the organizations providing the service to adapt and use that technology.

40. Ibid, p.

41. Such as guards against misrepresentation of products and of costs and risks.

42. "Electronic Money: Provider Issues and Regulatory Structure", Report by the Working Group on Provider Issues Relating to Electronic Money of the Committee on Payment and Settlement Systems, Basel, June 1996 (Preliminary, Unpublished), p. 4)

43. Ibid, p. 5.

44. "Card Briefs: Two Firms to Promote Contactless Smart Cards," American Banker, Vol. 161, no. 97, May 21, 1996, On-line Edition

45. "French Smartcard Proves a Bright Idea", Compuserve News Services, 4/22/96, 6:08 a.m., Paris

46. Ashurst, Mark, "Visa launches multi-function smart cards", Financial Times, Novermber 12, 1996, p.7.

47. Foremski, Tom and Taylor, Paul, "Smartcards: a technology whose time has come", "Financial Times, Information Technology Section, October 2, 1996, p.1.

48. Mastercard International Press Release, "MasterCard International Agrees to Acquire $51 \%$ of Mondex International" , http://www.mastercard.com, November 18, 1996, 3:48 p.m.

49. Bank, David, "Smart Cards Are Open to New Attack by Hackers, Say Israeli Researchers", Wall Street Journal, October 21, 1996, p. A17.

50. Ogilvie, III, Charles W., "Cyberbanking: Risks on the New Frontier", Bank Management, May/June 1996, pp. 14-18.

51. Block, Valerie, "Smart Card Execs Questions Report on Breachability", American Banker, Vol. 161, no. 196, October 11, 1996, On-line Edition

52. Bank, David, "Smart Cards Are Open to New Attacks by Hackers, Say Israeli Researchers", Wall Street Journal, October 11, 1996, p. A17.

53. Block, Valerie, "Smart Card Execs Question Report on Breachability", American Banker, Vol. 161, no. 189, October 2, 1996, On-line Edition.

54. Ibid.

55. Lampru, Paul,"Traditional and Public Key Cryptology: An Introduction”, Verifone Presentation, September 19, 1995 Version, p.9.

56. "Going for Olympic Gold", The Economist, March 30, 1996, p. 68.

57. "Digitising dollars", The Economist, March 30, 1996, p. 68. 
58. Ibid.

59. Santos, Filipe, "SIBS Approach to the Electronic Purse in Europe", Payments System Worldwide, London, Spring 1996, p. 20.

60. This was the recommendation contained in the $1994 \mathrm{EMI}$ report. There have been some exceptions already to this recommendation, such as the Primeur card in the Netherlands, but that is a "closed" system at this time.

61. Ibid, p.19.

62. Herring, Richard J. and Litan, Robert E., Financial Regulation in the Global Economy, The Brookings Institution, Washington, D.C., 1995, p. 43.

63.Bloom, Jennifer Kingson, "Web Pioneers Unite to Seek Open Standard for Payments", American Banker, April 18, 1996, p. 1.

64.Bloom, Jennifer Kingson, "Rivals Unite on Rules for Internet Commerce", American Banker, November 14, 1996, p. 16.

65.Ibid.

66.Ibid.

67.Allen, Catherine and Barr, William J., editors, Smart Cards, Seizing Strategic Business Opportunities, Irwin Professional Publishing, Chicago, 1996, p. 14.

68. Ibid, p. 15.

69.Block, Valerie, "Card Frontiers: Industry Standard Eyed for Smart Card Keys to PC Networks," American Banker, Vol. 161, no. 174, September 11, 1996, On-line Edition.

70.Melzer, Thomas C. “A Central Banker's Perspective”, Bank Management Journal, January/February 1996, pp. 53-56.

71.Kutler, Jeffrey, "Smart Card Forum Eyes Past for Light on Present", American Banker, September 24, 1996, p. 5. 


\section{BIBLIOGRAPHY}

Allen, Catherine and Barr, William J., editors, Smart Cards, Seizing Strategic Business Opportunities, Irwin Professional Publishing, Chicago, 1996.

American Banker, "Card Briefs: 3 Australian Banks Testing Mastercard Smart Cards", Vol. 161, No. \#63, April 1, 1996, On-line Edition.

Ashurst, Mark, "Visa launches multi-function smart cards", Financial Times, November 12, 1996, p.7.

Bank, David, "Smart Cards Are Open to New Attack by Hackers, Say Israeli Researchers", Wall Street Journal, October 21, 1996, p. A17.

Basel Committee, "Electronic Money: Provider Issues and Regulatory Structure", Report by the Working Committee on Provider Issues Relating to Electronic Money of the Committee on Payments and Settlement Systems, Basel, June 1996 (Preliminary, unpublished).

Bauer, Paul W., "Making Payments in Cyberspace", Economic Commentary, Federal Reserve Bank of Cleveland, October 1, 1995.

Block, Valerie, "Card Frontiers: Industry Standard Eyed for Smart Card Keys to PC Networks, American Banker, Vol. 161, no. 174, September 11, 1996, On-line Edition.

Block, Valerie, "Card Frontiers: National City Pilot Testing Smart Card for Schoolkids", American Banker, Vol. 161, no.179, September 18, 1996, On-line Edition.

Block, Valerie, "Cybercash, Mondex Team Up To Put Smart Card on the Web,"American Banker, Vol. 161, no. 186, September 27, 1996, On-line Edition.

Block, Valerie, "Smart Card Execs Question Report on Breachability", American Banker, Vol. 161, no. 189, October 2, 1996, On-line Edition.

Block, Valerie, "Smart Card Venture, Once Written Off, Is Perking Up", American Banker, Vol. 161, no. 196, October 11, 1996, On-line Edition.

Block, Valerie, "Smart Bits: New Zealand Banks Start Mondex Pilot", American Banker,

Vol. 161., no. 209, October 30, 1996, On-line Edition.

Block, Valerie, "In S. Africa, Visa Test Smart Card Linked to Banks", American Banker, November 13, 1996, p. 20.

Block, Valerie, "American Express to Use Smart Card Technology of Belgian Banks' Banksys", American Banker, Vol. 161, no. 220, November 15, 1996, On-line Edition.

Block, Valerie, "Mastercard Will Buy 51\% of Smart Card Firm Mondex", American Banker, Vol. 161, no. 222, November 19, 1996, Online Edition.

Bloom, Jennifer Kingson, "Web Pioneers Unite to Seek Open Standard for Payments", American Banker, April 18, 1996, p. 1. 
Bloom, Jennifer Kingson, "Rivals Unite on Rules for Internet Commerce", American Banker, November 14, 1996, p. 16.

Board of Governors of the Federal Reserve System, "Official Staff Commentary on Regulation E Electronic Fund Transfers", Washington D.C., Amended May 2, 1996.

Bright, R., Smart Cards: Principles, Practices, Applications, Halstead Press, New York, 1988.

Bucciarelli, Louis L., Designing Engineers, MIT Press, Cambridge, Massachusetts, 1996.

Burt, Tim, "Master Card seeks majority stake in smart card group", Financial Times, November 8, 1996, p. 1.

Business Week, "Cash - Choice form of Payments", April 8, 1996, p.24.

Canada News Wire, "Mondex Unveils Card for Guelph, Ontario Pilot", June 31, 1996,

http://www.newswire.ca/releases/June 1996/03/c0194.html, visited November 18, 1996, 15:46:33.

Castaneda, Laura, "The Cashless Future”, San Francisco Chronicle, September 25, 1996, p. B1.

Congress of the United State, Congressional Budget Office, "Emerging Electronic Methods for Making Retail Payments", Washington, D.C., June 11996.

CTIA News Media Relations, Washington, D.C., "Wireless Growth Sets New Annual Records", Press Release, September 19, 1996.

DeSenerpont Domis, Olaf, "For Stored Value Cards the Fed Proposes Light Consumer Regs", American Banker, March 21, 1996, p. 1.

DeSenerpont Domis, Olaf, "Capital Briefs: Regulation of Stored-Value Cards Opposed”, American Banker, Vol. 161, no. 223, November 20, 1996, On-line Edition.

"Dutch banks to be first with smartcards", Reuters News Service via Compuserve Online Service, October 4, 1996.

Foremski, Tom, and Taylor, Paul, "Smartcards: a technology whose time has come", Financial Times, Information Technology section, October 2, 1996., p. 1.

Fortune Magazine, "The Best of Business Travel”, Special Advertising Section, April 25, 1996.

Fox, Justin, “Cyberbunk: What's New About Digital Cash?”, Fortune, September 30, 1996, p. 50-54.

Giannone, J.A. and Jarman, A., "Visa's Chip Card Strategy”, Electronic Payments International, IV (April), p. 4.

Graham, George, “World tries a new way to pay,” Financial Times, November 8, 1996, p.3.

Grant, Lorrie, "Forget about digging old fashioned money out of your pocket during hectic moments", Reuters News Service via American Online, 4/16/95.

Hansell, Saul, "It's Coming: Your Pocket Cash on a Plastic Card", New York Times, Business Section, p. 
1., April 10, 1996.

Herring, Richard J. and Litan, Robert E., Financial Regulation in the Global Economy,

Brookings Institution, Washington, D.C., 1995.

Koprowski, Gene, "The Moneychangers: Digital Cash Innovators Talk Banks, Bits, Bytes, and Bucks", Fortune ASAP, August 26, 1996, pp. 68-74.

Krantz, Mark, "Electronic Cash Transfer Shakes Up Banking World", Investor's Business Daily, June 24, 1996, p. 4.

Krantz, Mark, "Electronic Cash Blooming in Less Developed Nations", Investor's Business Daily, June 25, 1996, p. 12.

Kutler, Jeffrey, "Europay Announces Advanced Multicurrency Smart Card", American Banker, Vol. 161, no. 109, June 7, 1996. On-line Edition.

Kutler, Jeffrey, "Fed Up with Mondex? Not So, Natwest Says", American Banker, Vol. 161, no. 131, July 11, 1996, On-line Edition.

Kutler, Jeffrey, "Mondex, Moving Fast, Sees Long Trek to a Worldwide Cash Alternative", American Banker, Vol. 161, no. 177, September 16, 1996, On-line Edition

Kutler, Jeffrey, "Smart Card Forum Eyes Past for Light on Present", American Banker, September 24, 1996, p. 5.

Kutler, Jeffrey, “NEWS ANALYSIS: Atlanta Pilot Didn't Make Case for Visa Cash, Execs Say”,American Banker, Vol. 161,No. 189., October 2, 1996. On-line Edition.

Lacker, Jeffrey M., "Stored Value Cards: Costly Private Substitutes for Government Currency", Economic Review, Federal Reserve Bank of Richmond, Summer 1996.

Lampru, Paul,"Traditional and Public Key Cryptology: An Introduction", Verifone Presentation, September 19, 1995 Version.

MasterCard International Press Release, "Visa \& MasterCard Combine Secure Specifications For Card Transactions On The Internet Into One Standard", http://www.mastercard.com, February 1, 1996.

Melzer, Thomas C. "A Central Banker's Perspective", Bank Management Journal, January/February 1996, pp. 53-56.

Ogilve III, Charles W. "Cyberbanking: Risks on the New Frontier", Bank Management, May/June 1996, pp. 14-18

Rehm, Barbara A., "Not Just SAIF, But a Potpourri Affecting Banks", American Banker, Vol. 161, no. 189, October 2, 1996, Online Edition.

Santos, Filipe, "SIBS Approach to the Electronic Purse in Europe", Payments System Worldwide, London, Spring 1996, p. 20.

"Smart Cards", Compuserve Online Services, from AP, 4/11/96, 2:02 p.m.ET. 
Barbara Ann Good

Fall Semester 1996

Stuber, Gerald, The Electronic Purse, An Overview of Recent Policy Developments and Policy Issues, Bank of Canada, January 1996.

The Economist, "Going for Olympic Gold”, March 30, 1996, p. 67.

The Economist, "Digitising dollars", March 30, 1996, p. 68.

Toimiraha Ltd., The Finnish Electronic Purse, Brochure, not dated.

Tucker, Tracey, "Diebold Creates a Division for College Campus Cards", American Banker, March 31, 1996, p. 7.

Wenninger, John and Laster, David, "The Electronic Purse", Current Issues in Economics and Finance, Federal Reserve Bank of New York, April 1995.

Zoreda, Jose Luis and Oton, Jose Manual, Smart Cards, Artech House, Boston, 1994. 


\section{APPENDIX A:}

\section{Status of the Pilot Programs}

"The reason for all of these pilot programs is that no one has yet proven the business case. I'll be really interested to see if anyone makes money out of this." This is a quote from Mr. Eugene Lockhart. President of MasterCard International made earlier in this year. ${ }^{1}$ Ironically, this quote appears in a companion article to the announcement that MasterCard had agreed to buy a majority interest in Mondex International. ${ }^{2}$

It is true that no one has yet proved a business case for electronic money, but that has certainly not stopped the proliferation of pilot programs in the world. The table at the end of this section was compiled for the Basle committee and shows only the major pilots underway in the G-10 countries. This paper will look at the largest cardbased pilots that are currently underway or are planned for late 1996 or early 1997.

\section{MONDEX in Swindon, England}

A major experiment is currently underway in Swindon, England, conducted by Mondex, a unit of National Westminster Bank (referred to as NatWest) in conjunction with Midland Bank. NatWest was hoping to establish enthusiasm for an international consortium to market Mondex worldwide. The Hongkong and Shanghai Banking Corporation Limited announced in October 1994 that it would acquire the rights to franchise Mondex throughout most of Asia. ${ }^{3}$ In May 1995, the Royal Bank of Canada and the Canadian Imperial Bank of Commerce indicated that they had signed a letter of intent to buy the Canadian franchise for Mondex, which was later finalized. Wells Fargo Bank in San Francisco has the rights to offer the system in the United States. 
2

In July 1996, the 17 international global founders' organizations organized Mondex International to market the Mondex system worldwide. Late in 1996, a majority interest was sold to Mastercard International.

With the Mondex system, users can make purchases, transfer money in and out of bank accounts, and carry out transactions over the phone. Funds can also be transferred between cards by means of an electronic wallet. Electronic terminals of the retailers will be able to accumulate the total value of Mondex transactions, which can be deposited to the merchant's bank by telephone at any time.

The card itself is designed to be locked with a personal code, so that if the card is lost, no one can use the value of the card. The card is capable of holding up to five separate currencies at a time.

Swindon, an old railway town, was chosen as the test site because it seemed to be an average community ( population 190,000), located about 77 miles west of London. Furthermore, most big British retailers also have outlets in Swindon. Initial reported results from the test have not been especially encouraging. Although $70 \%$ of the local merchants in Swindon are on-line, only 10,000 people have received the Mondex cards; and the experiment seems to be off to less than a "roaring start." ${ }^{4}$ Although Mondex card users initially loaded cash from their bank accounts onto the cards, via automatic teller machines, telephones, or home computers, and were expected to buy goods and services from the shopkeepers, many users did not reload the cards a second time. However, Mondex executives say the test results are encouraging, they have offered very little in the way of specific results. ${ }^{5}$ This is not especially surprising though, as this is a marketing experiment, and a very expensive 
one at that.

Although some merchants agree that electronic cash could make their banking easier, because they can deposit the cash into their accounts over a telephone line at any time, there still needs to be a greater acceptance by what appears to be a reluctant public in Swindon to use the electronic cash card.

Despite the apparent reluctance of consumers to use the Mondex card regularly, the Mondex executives say that they will launch the card throughout Britain after learning what they can in the two-year test.

\section{MONDEX U.S.A. -- Wells Fargo Bank, San Francisco}

Wells Fargo Bank is currently running a pilot program in San Francisco, California with 900 cards issued to employees and acceptable at numerous merchant locations in close proximity to their headquarters. The structure of Mondex U.S.A. is slightly different from other Mondex organizations.

Mondex U.S.A. is set up as a limited liability corporation, and is part of Mondex International. Mondex U.S.A. will be franchising the rites to "licensee banks" with no restrictions on offering competing products such as Visa Cash. Although they are still considering other partners, most banks want to be licensee banks of Mondex U.S.A., not equity partners.

Mondex U.S.A. will be structured with two entities - Mondex Originator which will be a separately licensed liability corporation that issues Mondex value, and Mondex Services which will provide the servicing to the licensee banks.

The Mondex Originator will essentially play the role of a "mini-Fed." It will receive requests from licensee banks to purchase value at the start of the day for a fee 
of some sort, based on the amount of value the bank expects to need to redeem during the day. These banks will be able to purchase more value during the day, but at a premium over the early in the day fee. Mondex Originator will invest the reserve funds in government securities, such as Treasury securities and other agency issues, in a fund that will be managed by an investment company. There will be a stable pool of investments as well as a highly liquid portfolio for daily requirements. Although it is assumed that this pool will face requirements similar to those of a money market mutual fund, this will need to be clarified. The regulator of Mondex Originator has also not been identified, but is assumed to be the SEC or the Federal Reserve System.

Mondex Services will deal with the licensee banks and will conduct business at arms length from Wells Fargo Bank. They will handle the strategic alliances with companies such as NCR and Diebold for the development and provision of ATMs, the relationships with Unisys and Verifone for the development of the card readers for merchant use. It is expected that the licensee banks will actually handle the sale/lease of these card reading terminals. The current expectation is that there will be one card reading terminal that will handle credit card, debit card, and various types of stored value cards, such as Mondex, Visa Cash, and Proton (currently in trials in Belgium). 1997 will be a roll-out year for Mondex, as they sign up licensee banks and prepare for various loyalty programs and additional applications, as are listed in the table below. 


\section{Roll-out plans: ${ }^{6}$}

\begin{tabular}{|c|c|c|}
\hline Internet pilot & Early 1997 & Transfer value over the Internet \\
\hline $\begin{array}{l}\text { Licensee banks } \\
\text { Sign up }\end{array}$ & \multicolumn{2}{|c|}{ All year 1997 Roll-out in various cities } \\
\hline $\begin{array}{l}\text { MAOS } \\
\text { Multiple Applicatio } \\
\text { Operating Syster }\end{array}$ & $\begin{array}{l}\text { Early } 1998 \\
\text { on } \\
\text { m }\end{array}$ & $\begin{array}{l}\text { Chip able to take on "loyalty } \\
\text { programs"; add mass transit } \\
\text { systems; cellular phone value loading } \\
\text { capability(GSM phones); medical } \\
\text { records }\end{array}$ \\
\hline $\begin{array}{l}\text { MAOS } \\
\text { Chip Rollout }\end{array}$ & January 1998 & Run education programs \\
\hline
\end{tabular}

At this time, there is a limit of $\$ 300.00$ of value that can be held on the Mondex card, and a $\$ 10,000$ limit for transfer of value by merchants. It is estimated that in the future these limits on the Mondex card could be increased, possibly having a "gold" Mondex card or the value limits would be waived for some customers, based on the banking relationship and knowledge of their use of the card.

Currently, only the last 10 transactions are kept in the transaction log on the card. With the planned increase in the chip capacity, more transactions could be maintained. There are three separate logs on the card at this time - a payment log, a pending log, and an exception log.

The payment log contains the last ten transactions, while the exception log keeps track of incomplete transactions. This log sits off to the side and after 5 incomplete transactions, the card locks up. The card then needs to be returned to the issuer to be "cleared off." The pending log is the intermediate step, it keeps track of the 


\section{6}

most recent transaction until it is completed. These three logs are expected to be expanded as the chip's capacity is increased.

There are also additional security features such as the self-monitoring chip, which is sophisticated enough to know tampering has happened. There is also a transaction behavioral analysis that is available to the issuer. Today, if the chip on the Mondex card has been transferred or tampered with, the cards will not work as there has been a "break" in the value transfer protocol.

Although the Mondex card is designated as "unaccountable," meaning that it works more like cash than some of the other systems, it is auditable. The records of the merchant transactions contain an audit trail of transactions.

\section{MONDEX CANADA}

Guelph, Ontario is the first city in North America and the third in the world to be selected for introducing this smart card technology on a broad scale. Guelph, with a population of 100,000 , was selected as the Mondex launch community in Canada because of its broad socioeconomic profile of residents, its wide mix of large and small business, its well-patronized transit system and its large university population. Moreover, Guelph is at the center of Canada's Technology Triangle and has established a strong reputation for innovation, entrepreneurship and community spirit and pride. ${ }^{7}$

CIBC and Royal Bank of Canada, with Bell Canada began equipment installation and Guelph Mondex staff tested the system in September and October of this year. Some Guelph customers and merchants started to participate in the pilot in November with the full pilot established in the first quarter of 1997. The national roll-out for 
Mondex is scheduled to begin early in $1998^{7} .^{8}$

The Mondex Canada card was specially designed by the Toronto agency Harrod and Mirlin. The front of the card shows a representation of twenty dollar bills and identified either CIBC or Royal Bank, the cardholders name and the assigned card number. "The representation of the twenties is a graphic statement that the Mondex card can be used for more than simply coin or incidental purchases. Mondex has been designed to permit our customers to use their cards just as they do now with cash but with a wide array of convenience, accessiblity, and security benefits ... " stated the Products Division at CIBC. ${ }^{9}$

\section{MasterCard Cash Canberra, Australia}

The initial showcase for the MasterCash Card is Canberrra, Australia. In March 1996, MasterCard launched its first pilot after almost a year's worth of preparation. The cash function is designed for transactions that are less than $\$ 10$ and tied to a bank account, therefore making it a "relationship card. ${ }^{10 \text { ", }}$

Three major Australian banks are participating in the pilot — New Zealand Banking Group, the Commonwealth Bank of Australia, and Westpac Banking Corp. It is expected that 10,000 cards will be issued to consumers and that 250 merchants will be involved. The MasterCard Cash cards have embedded computer chips that can be reloadable and also have magnetic strips that allow them to be used as conventional

credit or debit cards. ${ }^{11}$ Plans include testing a multi-currency card later in the pilot.

\section{Olympics Pilot -- Atlanta, Georgia}

Early in April 1995, First Union, the ninth largest bank in the United States (at that time), announced that it would introduce a million smart cards in Atlanta by the 
1996 Summer Olympics' cards and to other metropolitan areas in 1997. (Two other banks later formed a consortium and joined in this venture -- NationsBank and Wachovia.) Nonbank partners in this venture were BellSouth, Diebold and Schlumberger. The trial used an operating system developed by Visa to support the stored value cards, allowing the advertisment "Where the Visa logo appears, the consumer can use the card" ${ }^{12}$ to be displayed.

The trial involved both disposable and rechargeable cards, which were manufactured by Schlumberger. The cards were issued in denominations of $\$ 25, \$ 50$, and $\$ 100$ and were expected to be popular with consumers who travel and lack a local bank account. Cards were issued to each athlete that could be used for any purchase, from a meal to a masseur. ${ }^{13}$ The cards were expected to be most likely accepted by foreign travelers, especially Europeans, who are more accustomed to prepaid cards than Americans. Shortly thereafter, MasterCard announced that they too would be running a trial during the Summer Olympics.

The Olympics' trial was considered a success by the participants, but consumer acceptance was fairly lukewarm, in the words of one expert, "instructive, but not definitive ${ }^{14} . "$ However, the cards issued helped to increase the consumers' knowledge about and acceptance of this new payment device. The fledgling U.S. market for collectible stored value cards however took a giant leap forward, as people often bought the cards as souvenirs, not using the value on them at all in some cases, and in other cases, retaining at least a portion of the value on the card.

Both MasterCard and Visa felt that much was learned from the pilot and that they would gain additional information in the Upper West Side of Manhattan, New York pilot 
9

later in the year (subsequently postponed until late 1997). One aspect that was learned was that merchant acceptance and training "absolutely must be addressed" according to a Citibank project manager ${ }^{15}$.

\section{Manhattan Test}

Citibank, Chase Manhattan, MasterCard and Visa announced an ambitious plan for a joint venture that would offer electronic cash loaded on a plastic card. This was an unusual cooperation between the nation's two largest banks and the two largest card companies, all long rivals. ${ }^{16}$ "By choosing to issue cards in both the MasterCard and Visa electronic cash programs, the two New York banks are helping to establish standards for card reading equipment that will help speed the deployment of compatible cards in other regions. Indeed, cards issued in Visa's elaborate electronic cash program at the Atlanta Olympics will work at all of the New York locations." ${ }^{17}$

Customers and merchants were be solicited for this trial on the Upper West Side of Manhattan. However, as the area's residents have among the highest levels of automated teller machine usage in the city, the banks do not think finding participants will be a problem. The banks will offer some of the cards free and others with fees. The bankers feel that ultimately customers will be willing to pay a monthly fee of $\$ 1.00$ or $\$ 1.50$, or a transaction fee to load the cards. Merchants who participate will have the $\$ 500$ to $\$ 1,000$ cost of the card readers subsidized. It is assumed that eventually merchants will be charged a transaction fee, just as they now are charged on debit and credit card transactions.

PROTON - BENELUX

Proton, developed in 1995 by Banksys, a payment service company owned by 
60 Belgian banks, is in pilot or a rollout phase in seven countries. Proton was one of the pioneering stored value card systems and was originally announced in 1993. As of May 1996, 30,000 cards had been issued and 300 loading devices were in place. The average amount put on the cards was $\$ 43$, with an average transaction of $\$ 8$. In early 1997, Banksys plans to merge their debit card and stored card capabilities. ${ }^{18}$

Proton technology is incorporated into the Netherlands' Chipknip program, Brazilian PROTON program, and Australia's QuickLink. Sweden and Switzerland also have Proton-based technologies in preparation. In Canada, Toronto Dominion Bank, Bank of Montreal and Canada Trust are launching the Exact program. ${ }^{19}$

In November 1996, American Express was the first major card company to announce that it had licensed smart card technology, when they signed an agreement with Banksys. The New York based financial services company said it would use the Banksys smart card system to develop multi-application programs for the travel and entertainment sectors. $^{20}$

\section{Europay Clip}

In June 1996, Europay International, entered the arena with its smart card program Clip. It is one of the most ambitious stored value proposals of any banking group. Europay is MasterCard's European marketing partner and has been "explicitly" opposed to the unauditable aspects of other leading cards. ${ }^{21}$

Europay announced that it would issue a multinational, multi-currency system that would put it in the lead in the race against other chip card promoters. In 1994, ahead of MasterCard and Visa, Europay formally made a long-term commitment to the chip, with the migration now scheduled to take place from 1997 to $2002 .^{22}$ 
Helping to advance Clip are banks that have already agreed to integrate the Europay system in their electronic purses, and these are banks in Italy, Iceland, and the Czech Republic. And Austria may not be far behind.

Technically, Clip is ahead of any other such ventures as it incorporates the latest EMV technical standards, EMV-3, the chip card interoperability principles that Europay developed with MasterCard and Visa. ${ }^{23}$

\section{The Netherlands Program}

Dutch banks are poised to become the first in the world to introduce computer smart cards on a nationwide scale this year, eventually giving 15 million people the possibility of living their lives without cash. ${ }^{24}$ Dutch banks will start issuing smart cards to their clients this month and by October 1997 all 15 million people in the Netherlands will have access to them.

The Dutch smart cards are not just reloadable cash cards but can also be used for on-line bank transfers, retail loyalty schemes such as air miles, teleshopping, and ticket reservations. A Dutch consumer can store small amounts of cash on a card which can be used even for purchases such as ice cream or bus fares. The money will be transferred from the card to the retailer's account without costly on-line links via the bank.

For more expensive purchases the transaction will be on-line validated by the customer's secret four digit individual code. "Smart cards" can be loaded at "cash dispensers," but by the end of 1996 it will also be able to load value from home via smart phones or cheap "home loaders" connected to an ordinary telephone.

There will be two sets of Dutch smart cards, issued by two groups of banks, 
12

Rabobank and ABN Amro on one side with their "Chipknip," and Postbank \&PTT Telecom on the other with the "Chipper." ${ }^{25}$ The Chipknip card has slightly more memory than the other which will make payments more secure according to a spokesman. The Chipper consortium claims that its card has a multi-functional character. Both sides agree that the Netherlands is too small for two different standards and is discussing ways that there can be cooperation on one standard for the country.

\section{Other Pilots and Programs}

In Denmark the DANMONT card is now used in vending machines, phones, trains, buses, and parking meters. The cards in use are mainly disposable, though a reloadable card began to be issued in August $1995 .{ }^{26}$ This system is offered by the Danish payments organization and the Copenhagen Telephone Company, on behalf of all Danish telephone companies. The main goal of the Danish system at this time is to reduce coin collection costs. ${ }^{27}$ Visa has bought the rights to this technology. ${ }^{28}$

Finland's Avant card, in operation in some cities for two years already, has been phased in to cover the entire country at the end of $1995 .{ }^{29}$ This system is offered by the Bank of Finland, who has set up a subsidiary, Toimiraha, Ltd., specifically entrusted with developing and marketing its own version of an electronic purse. Clearly the Bank of Finland considers this innovation to be a viable and efficient replacement for coins and small dollar transactions. ${ }^{30}$

Lufthansa, the German airline, introduced earlier this year its new Chip-In Card system at airports in Germany. With this card, one makes reservations by providing the agent with a personal chip card number. When arriving at the airport, travelers pass 
13

their card in front of an ATM-style terminal and transfer the information from the card to the terminal. The machine then prints out the departure gate, boarding time, seat number, and mileage credit. This same card is also a boarding pass and baggage claim check. ${ }^{31}$ Although this is still a "closed" system, it performs considerably more functions than those "closed" systems discussed previously. And it could easily be expanded for additional travel needs, or expanded for other airline's or hotel's use.

There are a number of single-purpose and limited-purpose prepaid card applications in the United States, and some in operation for as long as ten years. The most notable are those involving mass transit systems, such as the Metro System in Washington, D.C., and on college campuses, where prepaid cards are commonly used for copying machines and in the cafeterias. Regional telephone companies have been selling prepaid calling cards for several years. These systems however, are considered "closed" systems. An "open" system would allow consumers to use a single card at a variety of locations for a broad range of purchases. These cards are commonly referred to as "electronic purses.",32 The differing designs will be addressed in Section III, Design Issues.

Lesser developed countries are also seen as targets for these electronic money schemes. "Developing nations are using smart cards to leapfrog the need to build telecommunications infrastructures," stated Jean McKenna, of the Smart Card Forum. ${ }^{33}$ Zambia, Thailand, Russia, the Czech Republic are all ahead of the United States in testing this new payments technology. It is assumed to be because they don't have competing payment systems and their citizens need more efficient banking services.

Developing countries also need a simpler system than credit or debit cards that 
require powerful networks to authorize and transfer payments.

South Africa has been experimenting with stored value cards for six years and has developed a national standard for a sophisticated product that reduces vulnerability to fraud, violent crime, and compensates for a lack of a communications infrastructure. The card contains three "purse" applications --one stores value on the chip and is used for small dollar transactions, another is used for larger cash transactions and required a personal identification number (PIN), and a third accesses a bank credit or debit account and requires a PIN. The transactions are fully auditable and are preauthorized and conducted off-line. ${ }^{34}$

1.Graham, George, "World tries a new way to pay," Financial Times, November 8, 1996, p.6.

2. Burt, Tim, "Master Card seeks majority stake in smart card group", Financial Times, November 8 , 1996, p. 1.

3. Stuber, p. 50.

4. "Smart Cards", Compuserve Online Services, from AP 4/11/96 2:02 pm ET.

5. Ibid.

6. Information received September $25^{\text {th }}, 1996$ during an personal interview with David Angier, Marketing Manager, Wells Fargo Bank, San Francisco., California.

7.Canada News Wire, "Mondex Unveils Card for Guelph, Ontario Pilot", June 31, 1996, http://www.newswire.ca/releases/June1996/03/c0194.html, visited Novmeber 18,1996, 15:46:33.

8. Ibid.

9. Ibid.

10.Allen, Catherine and Barr, William J., editors, Smart Cards, Seizing Strategic Business Opportunities, Irwin Professional Publishing, Chicago, 1996, pp. 52-53.

11.American Banker, "Card Briefs: 3 Australian Banks Testing Mastercard Smart Cards", Vol. 161, No. \#63, April 1, 1996, On-line Edition. 
12. Grant, Lorrie "Forget about digging old fashioned money out of your pocket during hectic moments", Reuters News Service via America Online, 4/16/95.

13. "Going for Olympic Gold", The Economist, March 30, 1996, p. 67.

14. Kutler, Jeffrey, "NEWS ANALYSIS: Atlanta Pilot Didn't Make Case for Visa Cash, Execs Say",American Banker, Vol. 161, No. 189.,October 2, 1996. On-line Edition.

15. Ibid.

16. Hansell, Saul, "It's Coming: Your Pocket Cash on a Plastic Card", New York Times, Business Section, p. 1., April 10, 1996.

17. Ibid.

18.Allen, Catherine and Barr, William J., editors, Smart Cards, Seizing Strategic Business Opportunities, Irwin Professional Publishing, Chicago, 1996, p. 54.

19.Block, Valerie, "American Express to Use Smart Card Technology of Belgian Banks' Banksys", American Banker, Vol. 161, no. 220, November 15, 1996, On-line Edition.

20. Ibid.

21.Allen, Catherine and Barr, William J., editors, Smart Cards, Seizing Strategic Business Opportunities, Irwin Professional Publishing, Chicago, 1996, p. 54.

22. Kutler, Jeffrey, "Europay Announces Advanced Multicurrency Smart Card", American Banker, Vol. 161, no. 109, June 7, 1996. On-line Edition.

23. Ibid.

24. Reuters News Service via Compuserve, October 4, 1996, "Dutch banks to be first with smartcards".

25. Ibid.

26. "Going for Olympic Gold", The Economist, March 30, 1996, p. 67.

27. Stuber, p. 16.

28. "Going for Olympic Gold", The Economist, March 30, 1996, p. 67.

29. Ibid, p.2.

30. Toimiraha Ltd., The Finnish Electronic Purse, Brochure, not dated.

31. "The Best of Business Travel", special advertising section of Fortune Magazine, April 25, 1996.

32. Wenninger, John and Laster, David, "The Electronic Purse", Current Issues in Economics and 
Finance, Federal Reserve Bank of New York, April 1995, p.1.

33.Krantz, Mark, "Electronic Cash Blooming in Less Developed Nations", Investor's Business Daily, June 25, 1996, p. 12.

34.Block, Valerie, "In S. Africa, Visa Test Smart Card Linked to Banks", American Banker, November 13, 1996, p. 20. 


\section{APPENDIX B}

\section{Regulations in the G-10 Countries}

The EU countries can be divided into three broad groups in terms of the current position of both legislation and regulation.

Belgium, France, Italy, and the Netherlands - credit institutions are thought to be covered under the existing banking law. In principle, the regulatory structure establishes that the providers of multipurpose cards must be credit institutions and meet specific statutory requirements.

Germany and Sweden - Currently there are no legislative restrictions on the types of providers, but the banking law will most likely be amended in accordance with the 1994 EMI report.

In Germany, it is expected that the issuance of prepaid cards will be added to the catalogue of banking business. This will mean that issuers of those cards that are multipurpose and that represent generally accepted purchasing power will be regarded as credit institutions and subject to all bank supervisory requirements. There will be some modification for those card issuers that are involved in "Smaller card systems." It has been proposed that a provider of a smaller card system in which there are upper limits on the storable electronic value on the card and the number of issuable cards would be exempt from a number of supervisory requirements, but would have to comply with disclosure requirements and audit and inspection."1

In Sweden, the Banking Law is currently being reconsidered and electronic money is likely to be addressed. It is assumed that the changes to the Banking Law would follow the view of the EMI report that only credit institutions would be allowed to 
issue multi-purpose prepaid cards. ${ }^{2}$

The United Kingdom - There exists some uncertainty as to whether the issuance of electronic money is a deposit in accordance with the Banking Act of 1987. The Bank of England currently subscribes to the views contained in the $1994 \mathrm{EMI}$ report, but believes that the legal and regulatory position concerning usage and development of electronic money products should be kept under review. ${ }^{3}$

One aspect of electronic money that is not addressed in many of the EU countries' current legal system is the network-based non-card schemes (computer based). This will need to be addressed as these systems become more prevalent. In the non-European Union countries, there are no logical groupings of country's regulatory positions.

Canada - Various issues relating to electronic money are currently under discussion, with the possibility of introducing new legislation or amending the current legislation.

Electronic money providers who are federally regulated financial institutions would be subject to the requirements imposed by the Office of Supervision of Financial Institution (OSFI). The OFSI would have to approve the establishment of a subsidiary by a financial institution whose purpose was the issuance or electronic money. However, if the provider were not a financial institution, it would not be subject to OFSI requirements.

Japan - Japan has the Prepaid Card Law, defining a number of regulatory requirements specifically directed at the issuers of prepaid cards, such as prior notification and registration and the deposit of cash or eligible securities amounting to $50 \%$ of more of the unused balance of the prepaid cards issued. This law seems to be 
3

the only specific legislation pertaining to prepaid cards money in the G-10 countries. ${ }^{4}$ The law does not specify what institutions can issue prepaid cards and does not address whether the issuance of these cards could be considered deposit-taking from a regulatory standpoint. ${ }^{5}$

Providers will be required to notify or register with the Ministry of Finance (MOF) which has the power to revoke the registration, order a partial suspension of business, conduct on-site examination and give collective orders.

Switzerland - In the course of the total revision of the Swiss Federal Constitution, amendments to the Swiss monetary system have been discussed and it is anticipated that legislation for electronic money might be included in those amendments.

While there is no legal framework that legitimizes any regulatory action concerning electronic money, it is assumed that if the provider is a bank authorized under the Banking Law, the Federal Banking Commission would supervise it for compliance to the Banking Law.

United States - The Federal Reserve has requested comments regarding its Regulation E (these are discussed in detail in an earlier part of this section). In general, the stance of the regulators is that although these prepaid cards and other electronic money schemes are evolving rapidly, the existing regulatory framework remains adequate to address the developments to date. And as they do not wish to hamper innovation, no immediate response to these emerging payment devices will be undertaken.

In the case of non-bank issuance, no specific asset restrictions or regulations 
4

related specifically to electronic money currently exist. However, a number of existing regulatory measures may be applicable. Banking authorities would have powers to examine non-bank electronic money systems in which banks participate and could prohibit participation if the system posed safety and soundness risks to the banking institution.

1. "Electronic Money: Provider Issues and Regulatory Structure", Report by the Working Group on Provider Issues Relating to Electronic Money of the Committee on Payment and Settlement Systems, Basel, June 1996 (Preliminary, Unpublished), p. 16.

2.lbid, p. 15.

3. Ibid, p. 15.

4. Ibid, p. 16.

5.If the issuance of prepaid cards is considered deposit-taking, only banks would be eligible to be issuers. 